\title{
Iron Compounds in Controlled Radical Polymerization: Ferrocenes, (Clathro)chelates, and Porphyrins
}

\author{
R. M. Islamova \\ St. Petersburg State University, Universitetskaya nab. 7-9, St. Petersburg, 199034 Russia \\ e-mail: r.islamova@spbu.ru \\ Received October 1, 2015
}

\begin{abstract}
Experimental data on the application of metal complexes in radical polymerization of vinyl monomers collected over the recent 15 years have been analyzed and generalized. Special attention has been given to (un)substituted ferrocenes, macrocyclic (clathro)chelates, and iron porphyrinates as well as to the approaches to enhance their catalytic activity in controlled synthesis of macromolecules. The mentioned systems have been compared with each other as well as with selected complexes of other transition metals. It has been shown that the electronic and spatial structures of the metal complexes are related to their efficiency in the radical polymerization reactions.
\end{abstract}

Keywords: controlled radical polymerization, metallocene, (clathro)chelate, metal porphyrinate, catalytic/ initiating system

DOI: $10.1134 / \mathrm{S} 1070363216010217$

Application of metal complexes opens broad prospects to control the polymerization processe and to prepare polymer materials with improved physicochemical properties. The metal complex catalysis has become of special importance in the field of controlled radical polymerization over the recent 15 years.

The term "controlled radical polymerization" is generally referred to "living" or "pseudo-living" radical polymerization; its mechanism, irrespectively of the type of the catalysts/mediators applied (metal complexes [1-11], nitroxyl compounds [12-14], thioesters $[15,16]$, etc.) is based on minimization of the probability of the interaction between the propagating radicals, resulting in the irreversible chain termination. This allows for control of molecular parameters of the prepared polymers, in particular, reduction of the polydispersity coefficient down to $M_{\mathrm{w}} / M_{\mathrm{n}}=1.1$, achieving the linear behavior of the number-average molecular mass $\left(M_{\mathrm{n}}\right)$ as function of the conversion, elimination of the undesirable gel effect, and preparation of block copolymers.

Atom Transfer Radical Polymerization (ATRP) [1], Transition Metal-Catalyzed Living Radical Polymerization [7], and Organometallic Mediated Radical Polymerization (OMRP) [11] are among the types of controlled radical polymerization. The first approach is based on the use of halides of organic complexes of transition metals, leading to the formation of labile terminal carbon-halogen bond $\left(\mathrm{P}_{\mathrm{n}}-\mathrm{Hlg}\right)$. Under certain conditions, this bond is capable of dissociation to regenerate the initial or new active radical further propagating the polymer chain (Scheme 1).

Here $\mathrm{P}_{\mathrm{n}}$ stands for the propagating macroradical, $\mathrm{M}$ is the vinyl monomer, $\mathrm{HlgMt}^{x+1} / \mathrm{L}$ is the metal complex halide (with $\mathrm{L}$ as the organic ligand), Mt is the transition metal, and $k_{\mathrm{p}}$ is the rate constant of the chain propagation.

The second of the listed methods uses stable radical organometallic species or diamagnetic transition metal complexes forming the carbon-metal bond $\mathrm{P}_{\mathrm{n}}-\mathrm{Mt}$ as the regulators of the polymer chain growth [11] (Scheme 2).

Due to the similarity of these two approaches their simultaneous operation is often assumed [11].

Besides "living" radical polymerization, complexand/or coordination-radical polymerization discovered

Scheme 1.

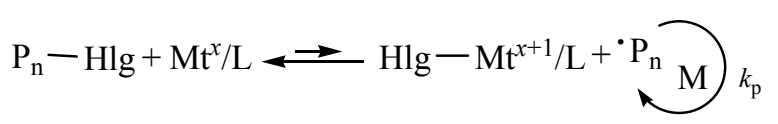


Scheme 2.

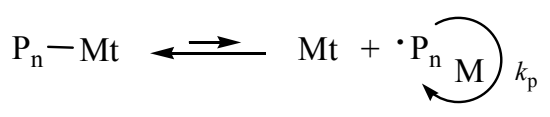

in 1960ies has been recognized as being of high importance in polymers synthesis; this method allows for the similarly efficient control of the polymer chain propagation via the complex formation between halides of non-transition metals (primarily the Lewis acids) [17] or organic compounds of II-V groups elements [18] with monomers and/or macroradicals. The effect of certain Lewis acids on the stereochemical composition of the macromolecules prepared via radical polymerization has been reported [17, 19-21]. The "stereospecific radical polymerization" term has been suggested by the Japanese scientists to describe such processes [20, 21]. However, in view of the recently reported data on the effects of structurally diverse metal-containing compounds on the radical polymerization with the character of stereoregular, complex-, and/or coordination-radical behavior $[8,17$, 18, 22-24], such processes rather should be regarded as metal-complex radical polymerization, since these processes are based on the complex formation between the metal compound with the macroradical and/or monomer, resulting in the polymer chain propagation vie the cyclic reaction complex $[17,18]$.

Hence, metal complexes are among the key components of the controlled ["living" and/or metalcomplex] radical polymerization opening wide prospects of targeted macromolecular design and energyefficient preparation of a series of the polymer products with improved properties.

Metal-complex catalysis in radical polymerization has been discussed in a number of reports so far [1-11]. However, the range of the applied catalysts has been mainly limited to the expensive copper $[1,25,26]$ and ruthenium $[5,7]$ compounds. At the same time, successful practical implementation of scientific ideas (including the industrial application) requires that the starting components are highly efficient, selective, relatively cheap, stable at storage, non-toxic, and safe during the operation. In view of this, catalysis with iron complexes meeting most of the above-listed demands is advantageous for performing the controlled radical polymerization.

Application of iron compounds in OMRP and ATRP processes has been relatively poorly discussed; in [11] deals with certain iron complexes with phosphine, imine, and other ligands. The present review is focused on such classes of compounds as ferrocenes, macrocyclic (clathro)chelates, and iron porphyrinates as well as on the approaches to enhance their catalytic activity in the controlled radical polymerization; the relevant comparative analysis is included.

Metallocenes. Metallocenes have been used in the polymerization (primarily the ion-coordination) processes over more than three decades [27]. The metallocene systems have been widely implemented in the industry since 1990ies, owing to the high catalytic activity, narrow molecular mass distribution of the prepared polyolefins, the ability of catalyzing ethylene copolymerization with higher $\alpha$-olefins, and the capacity to alter the catalytic properties via variation of the ligands structure; this has been referred to as "metallocene revolution" [28, 29]. In view of radical polymerization, metallocenes are interesting as components of catalytic/initiating systems allowing for control of the polymerization process and preparation of vinyl polymers with improved physicochemical characteristics.

First reports on the metallocenes application in radical polymerization (however, fairly scarce) appeared in 1970ies. The detailed studies of the metallocenes effect on the radical polymerization have been reported in [22-24, 30-43], the considered metallocenes including complexes of iron [22, 23, 30$35,39,43]$, titanium [23, 36-38, 40, 41], zirconium $[24,38,42,43]$, molybdenum [44, 45], cobalt [46], ruthenium $[47,48]$, etc.

Acceleration of styrene polymerization upon introduction of ferrocene 1 (Scheme 3 ) in the presence of peroxide initiator was marked more that forty years ago [49], but the basic investigation of the effect was performed relatively recently [30-33]. It was been found that the initial rate of styrene and methyl methacrylate polymerization (in bulk; in the presence of ferrocene 1; benzoyl, lauryl, or dicumyl peroxide at $0.2-2.0 \mathrm{mmol} / \mathrm{L}$ as the peroxide initiator; $60^{\circ} \mathrm{C}$; conversion of $\approx 5-7 \%$ ) increased about 4-7 times at the equimolar ratio of the ferrocene and the peroxide initiator, the molecular mass of the prepared polymers regularly decreasing. When AIBN is used as the initiator, the addition of the metallocene has practically no effect on the kinetic parameters of the process and the molecular parameters of the polymeric products. The effective activation energy of methyl methacrylate 
Scheme 3.

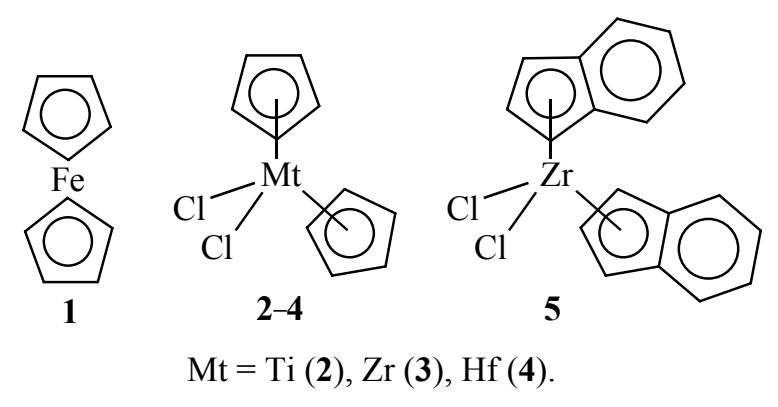

polymerization in the presence of the 1-benzoyl peroxide catalytic/initiating system is $48.3 \mathrm{~kJ} / \mathrm{mol}$, about twice lower than in the case of initiation with benzoyl peroxide alone. This in turn allows for preparation of poly(methyl methacrylate) at lower temperature, for instance, at $-4^{\circ} \mathrm{C}$. Average reaction rate orders with respect to ferrocene 1 and the peroxide initiator are 0.3 and 0.5 , respectively. The latter value has indirectly pointed at the radical mechanism of the reaction. The mechanism has been further confirmed by the fact that methyl methacrylate polymerization in the presence of ferrocene 1 occurs under conditions of photo initiation typical of radical polymerization [38].

A special feature of the methyl methacrylate polymerization initiated by the ferrocene 1-benzoyl peroxide system is its acceleration (the initial process rate is increased 1.5 or more times) in the presence of hydroquinone, radical inhibitor [31]. This may be related to reduction properties of both ferrocene and hydroquinone. Addition of ethanol (inhibitor of ionic polymerization) accelerates the polymerization as well, evidently due to the benzoyl peroxide decomposition induced by ethanol as electron donor [31]. Furthermore, unusual oscillatory changes of absorbance of ferrocene $\mathbf{1}$ ethanolic solution in time were reportd previously[50]. The association via hydrogen bonding between the ferrocene system and the alcohol molecules has been suggested. 4-Phenyl-2,2,5,5tetramethyl-3-imidazolin-1-oxyl efficiently inhibits the polymerization of methyl methacrylate in the presence of ferrocene 1 and benzoyl peroxide [31].

In further study the concentration range of ferrocene 1 has been extended to $10^{-2}-10 \mathrm{~mol} / \mathrm{L}$ [39]; it has been found that the metal complex excess leads to significant decrease in the process rate, and poly(methyl methacrylate) synthesis is no longer possible.

The presence of ferrocene 1 smoothed the gel effect at the high conversion of methyl methacrylate [43].
However, the polydispersity index determined at different conversions $\left(M_{\mathrm{w}} / M_{\mathrm{n}} 2.0-3.9\right.$ on the average) $[33,43]$ is noticeably higher than that typical of the "living" processes $\left(M_{\mathrm{w}} / M_{\mathrm{n}}=1.1-1.5\right)$ [1-16]. GPS analysis has revealed that polystyrene prepared in the presence of ferrocene 1 and benzoyl peroxide exhibits the kinetic inhomogeneity, owing primarily to the change in the active centers type [35].

The above-mentioned data do not allow assignment of ferrocene 1 to typical "living" mediators/catalysts [1-7]. At the same time, the effect of its presence is equally important since it allows for fast polymerization and improvement of the poly(methyl methacrylate) properties, in particular, its microstructure and thermal stability.

Stereoregularity is among the most important parameters of polymers, affecting their solubility, crystallinity, melting and glass transition points, mechanical properties, etc. However, the issue of stereo regulation in radical polymerization has remained open for long. It has been demonstrated that certain Lewis acids of rare earth elements [in particular, lanthanide triflates like $\mathrm{Y}(\mathrm{OTf})_{3}$ and $\left.\mathrm{Yb}(\mathrm{OTf})_{3}\right]$ increase the content of iso structures in poly- $N$-isopropylamide from 44 to $66 \%$. Fluorinated alcohols in combination with ruthenium complexes enhanced syndiotacticity of poly(methyl methacrylate) prepared at $0^{\circ} \mathrm{C}$ to $77 \%[19,51,52]$.

A series of reports on simultaneous control of stereo chemistry and molecular mass distribution of macromolecules have been recently published. This has been achieved by simultaneous addition of the Lewis acid (affecting the microstructure of the produced polymer) and the agent producing the "living" polymerization to the reaction mixture [52]. However, the Lewis acid facilitates the stereospecific growth of the polymer chain but simultaneously suppresses the effect of the second component, the product polydispersity reaching in certain cases $M_{\mathrm{w}} / M_{\mathrm{n}}=3.2$.

Addition of ferrocene $\mathbf{1}$ to the reaction mixture during methyl methacrylate polymerization innitiated by benzoyl peroxide increases the content of the syndiotactic triads in the obtained polymer from 56 to $65 \%$ at $60^{\circ} \mathrm{C}[30-33,43]$. The improved stereoregularity has been observed when other catalytic/ initiating systems are used, in particular, these containing titanocene (2), zirconocene (3), hafnocene (4), and diindenylzirconocene (5) dichlorides (Scheme 3) $[23,24,36,38,42,43]$. The formation of the $\mathbf{2}$-methyl methacrylate [23], 3-methyl methacrylate [24], and 5- 
methyl methacrylate complexes has been confirmed by the data of electron absorption, IR, and ${ }^{1} \mathrm{H}$ NMR spectroscopy [24, 42]. A weak coordination bond is formed between the transition metal atom and the oxygen atom of the carbonyl group, affecting the mechanism of the monomer addition to the macroradical.

Besides changing the poly(methyl methacrylate) microstructure, the addition of ferrocene 1 to the polymerization system improves the thermal stability of the product $[32,33]$. The decomposition of poly (methyl methacrylate) prepared via radical polymerization is known to be innitiated at the terminal unsaturated groups formed mainly via disproportionation of the macroradicals [53]. Evidently, ferrocene 1 can reduce the amount of these groups owing to the formation of the more stable terminal ferrocenylcontaining moieties. According to the discussion presented in [54], it is the presence of ferrocenyl fragments in the copolymer of vinylferrocene and butadiene with terminal hydroxy groups prepared via radical polymerization in the presence of AIBN that leads to the improved thermal stability of the polymer.

Further studies have focused on the combinations of ferrocene 1 with compounds containing heteroatoms [55]. The choice of 3,6-bis (o-carboxybenzoyl)- $N$-isopropylcarbazole 6 (Scheme 4) exhibiting the properties of tertiary amine has been primarily governed by its effect (stronger than that of metallocenes) on the microstructure of the poly(methyl methacrylate) prepared in its presence: the content of syndio structures is up to $72 \%$ in the case of the synthesis at $75^{\circ} \mathrm{C}$ [56]. However, the polymerization has been substantially decelerated in the case of the compound 6-organic peroxide. It has been anticipated that the combination of metallocene 1-5 and compound 6 in the catalytic/initiating system may preserve the stereo control simultaneously accelerating the polymerization. However, the investigation of polymerization of methyl methacrylate initiated by the three-component systems has shown that metallocene has the major effect on kinetic parameters of the polymerization and properties of the prepared polymer (see the table) [43, $55,57-60]$.

The influence of the nitrogen-containing component has been enhanced via addition of the compounds containing the ferrocenyl and the amine fragments in the same molecule. $N, N$-Dimethyl- $N$-(methylferrocenyl)amine $7[22,61]$ and azinyl derivatives of ferrocene 8-12 (Scheme 4) [62-64] have been chosen.
Behavior of amine 7 in the course of methyl methacrylate polymerization initiated with benzoyl peroxide or AIBN is in general similar to that of ferrocene $\mathbf{1}$. The effect of the amino group of compound 7 on the polymerization process has been more prominent than in the case of using compound $\mathbf{6}$ in the ferrocene $\mathbf{1 -}$ carbazole 6-benzoyl peroxide three-component mixture with the individual metal- and nitrogen-containing compounds. The more significant suppression of the auto acceleration at the high conversion of polymerization has been observed in the presence of amine 7 as compared to the ferrocene 1-benzoyl peroxide or ferrocene 1-carbazole 6-benzoyl peroxide systems. On top of that, the increased concentration of the nitrogen-containing ferrocene derivative in the system (as well as the increased content of carbazole 6 in the ferrocene 1-compound 6-benzoyl peroxide system) has resulted in retarding the polymerization. This feature was more typical of the systems containing tertiary amines rather than the metallocenecontaining ones. The data of electron absorption, IR, and NMR spectroscopy have shown that the amino group affects the stability of the formed amine 7benzoyl peroxide complex, its decomposition being slower than in the case of the ferrocene 1-benzoyl peroxide complex [65].

The synergetic effect of the metal- and nitrogencontaining groups has been the most striking in the cases of azinyl ferrocenes 8-12 [62-64]. Combining the studied hetarylferrocenes with peroxides has afforded the highly efficient catalytic/initiating systems, more active in comparison with the ferrocene 1benzoyl peroxide system, other conditions being the same. Even the combination of ferrocene $\mathbf{1}$ and pyridine in the catalytic/initiating system has not given so strong acceleration of polymerization as compounds 8-12. Evidently, in the case of the ferrocene 1pyridine-benzoyl peroxide three-component system, the reaction of the nitrogen-containing derivative with the peroxide has become less important, and the effect has been suppressed by the active metallocene component (like in the case of the unsubstituted metallocene-carbazole 6-benzoyl peroxide systems). Spectral studies have confirmed that the coordination with the peroxide initiator has been affected by both the ferrocenyl and the heterocyclic groups of the substituted ferrocenes.

1-Pyridylferrocene has been studied in combination with cyclic peroxides [66]. It has been shown that ferrocene $\mathbf{8}$ forms efficient catalytic/initiating systems 
Scheme 4.<smiles>CC(C)n1c2ccc(C(=O)c3ccccc3C(=O)O)cc2c2cc(C(=O)c3ccccc3C(=O)O)ccc21</smiles><smiles>[R]c1ccccc1-c1ccccc1</smiles>

7-12<smiles>[R]CN(C)[14CH2][14c]1[14cH]cccn1</smiles>
(8),<smiles>Cc1ccc2ccccc2n1</smiles>
(9),<smiles>Cc1c2ccccc2nc2ccccc12</smiles>

(10),<smiles>Cc1cnccn1</smiles>

(11),<smiles>Cc1ccncn1</smiles>
(12).

with 3,6-dicyclohexyl-9,9'-dimethyl-, 3,6-dicyclododecyl-9-cyclohexyl-, and 3,6-dicyclohexyl-9-cyclododecyl-1,2,4,5,7,8-hexaoxonanes 13-15 (Scheme 5) as well as with diacyl peroxides (benzoyl and lauryl peroxides); their application has resulted in the acceleration of methyl methacrylate polymerization, the decrease in the molecular mass of the product, and the improvement of its stereo regularity, i. e., the general trends have been preserved.

Besides the combinations of metallocenes and nitrogen-containing compounds, catalytic/initiating systems

Parameters of methyl methacrylate polymerization initiated by benzoyl peroxide in the presence of various iron compounds ${ }^{\mathrm{a}}$

\begin{tabular}{|c|c|c|c|c|c|c|c|c|}
\hline Parameter ${ }^{\mathrm{b}}$ & $\begin{array}{l}\text { Without } \\
\text { metal } \\
\text { complex }\end{array}$ & 1 & $1(6)$ & 7 & 8 & 20 & 30 & $1(3)$ \\
\hline$w_{0}{ }^{\mathrm{c}}, \mathrm{mol} \mathrm{L}^{-1} \min ^{-1}$ & 4.0 & 39.8 & 33.5 & 32.7 & 27.2 & 35.2 & 4.4 & 23.0 \\
\hline $\mathrm{P}_{\eta}^{-} \times 10^{-3 \mathrm{c}}$ & 15.6 & 1.2 & 1.4 & 2.5 & 3.5 & 4.2 & 4.0 & 0.4 \\
\hline $\mathrm{P}_{\mathrm{n}}^{-} \times 10^{-3 \mathrm{c}}$ & 8.0 & 1.0 & 1.2 & 2.1 & 3.1 & 2.3 & 3.0 & 0.8 \\
\hline$M_{\mathrm{w}} / M_{\mathrm{n}}^{\mathrm{c}}$ & 2.0 & 1.9 & 1.8 & 2.0 & 1.5 & 1.9 & 1.6 & 1.3 \\
\hline $\begin{array}{l}\text { Rate order with } \\
\text { respect to the (metal) } \\
\text { complex additive }^{c}\end{array}$ & - & 0.3 & $0.3(0)$ & 0.2 & 0.5 & 0.5 & - & $\begin{array}{l}0.3 \\
(-)\end{array}$ \\
\hline $\begin{array}{l}\text { Rate order with re- } \\
\text { spect to the initiator }\end{array}$ & 0.5 & 0.5 & 0.5 & 0.2 & 0.5 & 0.5 & 0.5 & $\begin{array}{l}\text { Deviates } \\
\text { from } 0.5\end{array}$ \\
\hline $\begin{array}{l}E_{\mathrm{a}}^{\mathrm{c}}, \mathrm{kJ} / \mathrm{mol} \\
(\text { calculated from data } \\
\left.\text { at } 30-75^{\circ} \mathrm{C}\right)\end{array}$ & $80 \pm 5$ & $43 \pm 3$ & - & $46 \pm 3$ & $44 \pm 3$ & $48 \pm 3$ & - & - \\
\hline Gel effect & $\begin{array}{c}\text { Starts at } \\
\text { conversion } \\
\text { of } 15-20 \%\end{array}$ & Smoothed & Smoothed & $\begin{array}{c}\text { Starts at } \\
\text { conversion } \\
\text { of } \sim 30 \%\end{array}$ & $\begin{array}{l}\text { Smoothed at } \\
{[\mathbf{8}] \geq} \\
2.0 \mathrm{mmol} / \mathrm{L}\end{array}$ & $\begin{array}{c}\text { Degenerate at } \\
{[\mathbf{2 0}] \geq 0.08} \\
\mathrm{mmol} / \mathrm{L}\end{array}$ & - & - \\
\hline $\begin{array}{l}\text { Syndio triads } \\
\text { content }, \%\end{array}$ & $55-56$ & 62 & 62 & 57 & 60 & 65 & 61 & 63 \\
\hline $\begin{array}{l}\text { Decomposition onset } \\
\text { temperature }{ }^{\mathrm{c}},{ }^{\circ} \mathrm{C}\end{array}$ & 224 & 255 & 270 & 264 & 270 & 254 & 250 & 262 \\
\hline
\end{tabular}




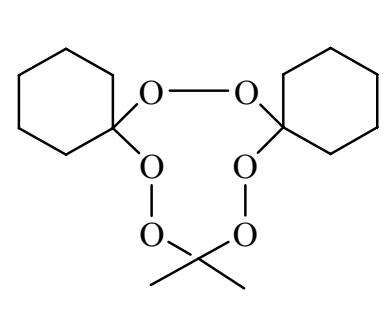

13

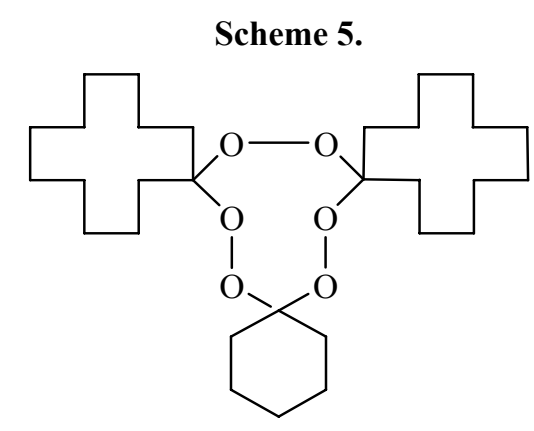

14

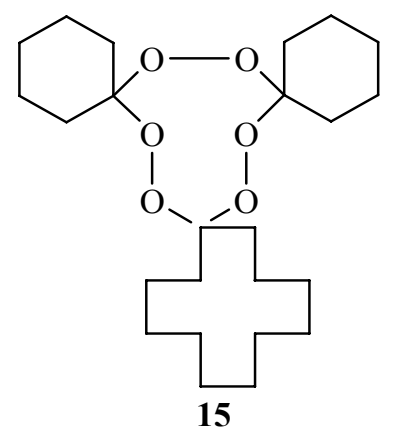

based on a pair of metallocenes have been developed [67-71]. The introduction of a pair of compounds of the same class into the polymerization system was expected to result in their additive effect, as observed in the case of combining compounds $\mathbf{2}-\mathbf{3}$ or 3-4 with organic peroxide. However, a combination of ferrocene 1 containing no chlorine atoms and forming the complexes with diacyl peroxides and dicyclopentadienyltitanium or hafnium chloride in the composition of the catalytic/initiating system has allowed for the "living" polymerization via RATRP (Reverse Atom Transfer Radical Polymerization) mechanism [1-4]. This has been evidenced by the decrease in the polydispersity index to $M_{\mathrm{w}} / M_{\mathrm{n}}=1.3$, a linear increase of $M_{\mathrm{n}}$ with conversion, and degeneration of the gel effect. Noteworthily, the presence of chlorine atoms in compounds 2-4 does not exclude the possibility of the "living" polymerization via ATRP or OMRP mechanism [1-11]. The possibility of formation of the metal-centered radical $\mathrm{Cp}_{2} \mathrm{TiCl}^{\circ}$ capable of controlling the polymer chain propagation both via the reversible deactivation and the atom transfer mechanism was considered in [41]. Evidently, depending on the conditions, metallocenes can act differently, facilitateing the polymerization via the "living" or complexradical mechanism. The presence of two metallocenes in combination with the peroxide initiator in the reaction mixture allows for simultaneous control of molecular mass distribution and of stereochemical composition of the macromolecules.

Unexpected results have been obtained in the study of methyl methacrylate polymerization initiated with benzoyl peroxide in the presence of ferrocene 1 in air [72]. Firstly, polymerization under these conditions occurs to high conversion of the monomer; secondly, this has been the first report disclosing the part of ferrocenium cation-radical in initiation of radical polymerization in the absence and in the presence of oxygen; on top of that, the report contains the first confirmation of formation of $\mu$-peroxodimer complex of ferrocenium cation. The stable oligomeric reactive site has been isolated, its initiating activity being higher than that of $\mu$-peroxodimer complex of ferrocenium cation and benzoyl peroxide.

Several studies are available containing the data on the effect of a series of semimetallocene iron(II) complexes of the $\left[\mathrm{FeLX}(\mathrm{CO})_{2}\right]$ type [with $\mathrm{L}=\mathrm{Cp}\left(\eta^{5}\right.$ $\left.\left.\mathrm{C}_{5} \mathrm{H}_{5}\right), \mathrm{Cp}^{*}\left(\eta^{5}-\mathrm{C}_{5} \mathrm{Me}_{5}\right), \mathrm{X}=\mathrm{I}, \mathrm{Br}\right]$ as well as binuclear iron(I) complexes of the $\left[\mathrm{Fe}_{2} \mathrm{~L}_{2}(\mathrm{CO})_{4}\right]$ composition (with $\mathrm{L}=\mathrm{Cp}, \mathrm{Cp}^{*}$ ) 16-19 (Scheme 6) in the presence of the $\left(\mathrm{CH}_{3}\right)_{2} \mathrm{C}-\left(\mathrm{CO}_{2} \mathrm{Et}\right) \mathrm{X}$ initiator $(\mathrm{X}=\mathrm{I}, \mathrm{Br})$ and, in certain cases, upon addition of titanium(IV) or aluminum isopropoxide [71]) on "living" polymerization of acrylates and styrene [73-76].

It has been found that the polymerization rate depends on the type of the ligand in the studied catalysts, increasing in the $\mathrm{FeCp}^{*} \mathrm{I}(\mathrm{CO})_{2}<\mathrm{FeCpI}(\mathrm{CO})_{2}<$ $\mathrm{FeCp} * \mathrm{Br}(\mathrm{CO})_{2}<\mathrm{FeCpBr}(\mathrm{CO})_{2}$ series; in other words, the more electron-donating $\mathrm{Cp}^{*}$ substituent reduces the process rate, both in the cases of the bromine- and iodine-containing complexes. The narrowest molecular mass distribution $\left(M_{\mathrm{w}} / M_{\mathrm{n}}=1.05-1.09\right)$ has been observed in the case of $\mathrm{FeCp} * \mathrm{I}$ combined with the iodine-containing initiator [74]. The process scheme following ATRP mechanism [2, 4, 7] has been suggested (Scheme 7).

Using the $\left[\mathrm{Fe}_{2} \mathrm{~L}_{2}(\mathrm{CO})_{4}\right]$ binuclear complexes (with $\mathrm{L}=\mathrm{Cp}, \mathrm{Cp}^{*}$ ) allows for control of molecular parameters without addition of titanium(IV) isopropoxide in the presence of the iodine-containing catalyst $\left(\mathrm{CH}_{3}\right)_{2} \mathrm{C}\left(\mathrm{CO}_{2} \mathrm{Et}\right) \mathrm{I}$ alone [74]. However, the increase of the iron(I) complexes concentration has resulted in the bimodal molecular mass distribution. 
Scheme 6.

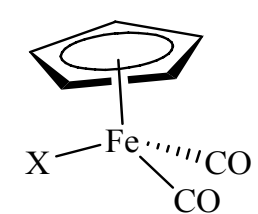

16

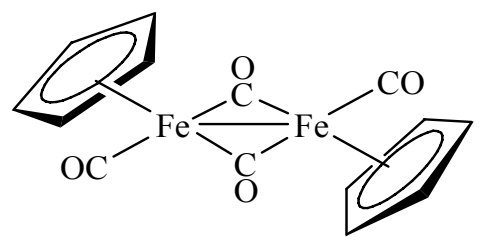

18<smiles>[X]C(C)(C(=O)[O-])C(C)=C(C)C(C)C</smiles>

17

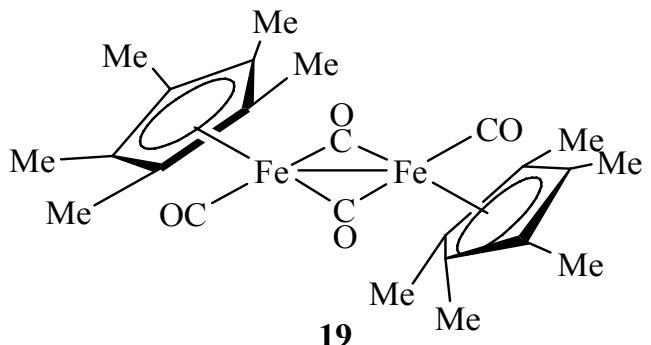

19

$\mathrm{X}=\mathrm{Br}, \mathrm{I}$.

Scheme 7.

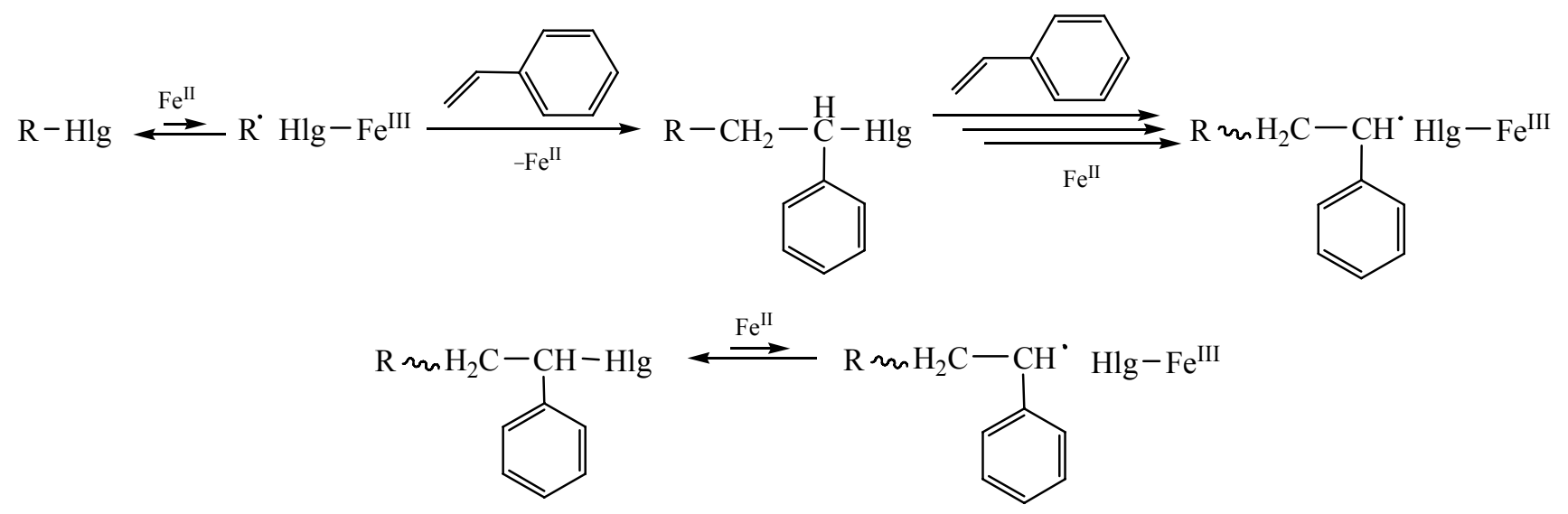

The semimetallocene iron(II) and iron(I) complexes in combination with the same radical initiators have been applied for polymerization of para-substituted styrenes [75]. It has been found that $\mathrm{FeCpI}$ initiated the faster polymerization of para-chlorostyrene (as compared to the unsubstituted analog) and was inactive towards para-methylstyrene due to the formation of terminal olefin, evidently, via $\beta$-elimination induced by iron(II) complex. In the case of paraacetoxymethylstyrene, the introduction of $\mathrm{Fe}_{2} \mathrm{Cp}_{2}(\mathrm{CO})_{4}$ has resulted in the broadening of the molecular mass distribution $\left(M_{\mathrm{w}} / M_{\mathrm{n}}=1.86\right)$, evidently owing to the reactions of chain transfer to the benzyl ester group. Titanium(IV) isopropoxide has not been used in polymerization of para-acetoxy- and para-acetoxy- methylstyrene due to the reactivity towards the monomers.

"Living" radical (co)polymerization of acrylates and styrene in the presence of the above-mentioned iron(II) semimetallocenes with the iodine-containing catalyst in aqueous suspension has been studied in [76]. The weak hydrophilic properties of cyclopentadienyl and carbonyl groups of the $\mathrm{Fe}(\mathrm{Cp}) \mathrm{I}(\mathrm{CO})$ complex afford its stability in water. At the same time, the $\left(\mathrm{CH}_{3}\right)_{2} \mathrm{C}-\left(\mathrm{CO}_{2} \mathrm{Et}\right) \mathrm{I} / \mathrm{Fe}(\mathrm{Cp}) \mathrm{I}(\mathrm{CO})$ system has exhibited higher activity in the presence of water than in the case of organic solvents.

To summarize, metallocenes (in particular, ferrocenes) form a promising class of compounds capable 


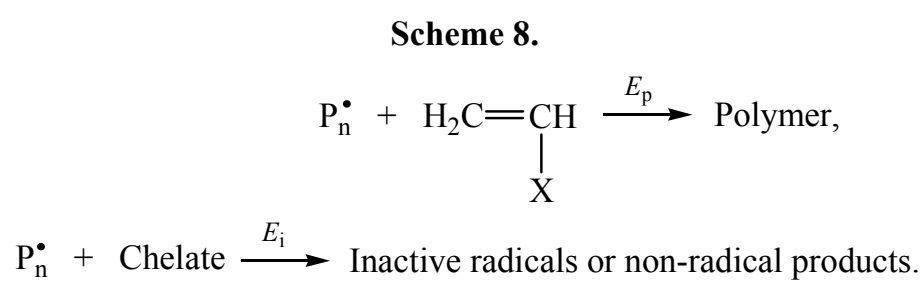

of controlling the course of radical polymerization of vinyl monomers and the properties of the formed polymers, owing to their specific interaction with peroxide initiators, monomers (primarily methyl methacrylate), and/or macroradicals, affecting all the process stages: initiation, chain propagation, and chain termination.

(Clathro)chelates. The information on application of chelate complexes in radical polymerization processes has been relatively scarce; however, these compounds are of interest as far as such processes are concerned.

It has been shown in [77] that chelates with macromolecular ligands based on poly- $\beta$-ketoesters can be used as catalysts in polymerization of methyl methacrylate and styrene, their activity being significantly dependent on the nature of the complex forming metal and the chelate concentration. For example, macromolecular chelates of cobalt and manganese are kinetically active in styrene polymerization but the conversion degree of the monomer is practically independent of the presence of the nickel chelate.

Certain transition metals tris(acetylacetonates) [primarily these of manganese(III) and cobalt(III)] exhibit the initiating activity owing to the thermal cleavage of the metal-oxygen bond and the transition of the metal to the lower oxidation state [78]. Addition of small amounts of different alcohols to manganese(III) tris(acetylacetonate) significantly increases the rate of vinyl acetate polymerization, enabling the process occurrence at low temperature. The alcohol concentration being the same, the polymerization rate is linear with the square root of the complex concentration, evidencing that the general radical mechanism is preserved. The reaction rate with respect to alcohol is 0.5 as well, confirming its participation in the polymerization. Effective activation energy of vinyl acetate polymerization in the presence of manganese(III) tris(acetylacetonate) and alcohols is lower than that in the presence of the complex alone $(96.2 \mathrm{~kJ} / \mathrm{mol})$. On top of that, the activation energy depends on the alcohol nature, the lowest value has been observed in the case of methanol $(34.0 \mathrm{~kJ} / \mathrm{mol})$.
Kinetics of decomposition of the manganese(III) tris(acetylacetonate)-benzoyl peroxide and iron(III) tris(acetylacetonate)-benzoyl peroxide systems has been studied in [79]. The decomposition rates of the metal complexes are close, but the activation energy of the iron complex decomposition is three times lower. In the case of the mixture of iron(III) and manganese(III) tris(acetylacetonates), the decomposition was 5-10 times faster than that in the cases of the individual complexes.

Methyl methacrylate polymerization initiated with cobalt(II) 3-allyl-pentan-2,4-dionate has been studied in $[80,81]$. The prepared polymers have been used as macroinitiators for grafting polymerization of methyl methacrylate. The process rate has been sufficiently high, and the molecular mass of the final product has been ten times higher than that of the macroinitiator, evidencing the high grafting degree.

It has been shown that increase in cobalt(II) vinyl$\beta$-diketonates content in the polymerization mixture (above $10^{-2} \mathrm{~mol} / \mathrm{L}$ ) decreases the polymerization rate and the products molecular mass, the polydispersity coefficient being increased [82, 83]. Long induction period has been simultaneously observed, resulting from the complex formation between the propagating radical and quasi aromatic $\beta$-diketonate cycles. It was suggested that vinyl- $\beta$-diketonates of transition metals acted both as the catalyst and the inhibitor, and the propagating macroradicals therefore participate in the two processes differing in the activation energy (Scheme 8).

Here $\mathrm{P}_{\mathrm{n}}$ is the propagating macro radical, $E_{\mathrm{p}}$ is the activation energy of the chain propagation, $E_{\mathrm{i}}$ is the activation energy of the macroradical termination at the inhibitor.

The ratio of the initiating and the inhibiting activity depends on the chelate concentration and other process conditions. In particular, the activation energy of the chain propagation in the case of styrene is $29.1 \mathrm{~kJ} / \mathrm{mol}$, and that of the radicals addition to the known inhibitors is $4.2-8.3 \mathrm{~kJ} / \mathrm{mol}$; the activation energy of the formation of adducts between the radicals with $\beta$ - 


\section{Scheme 9.}

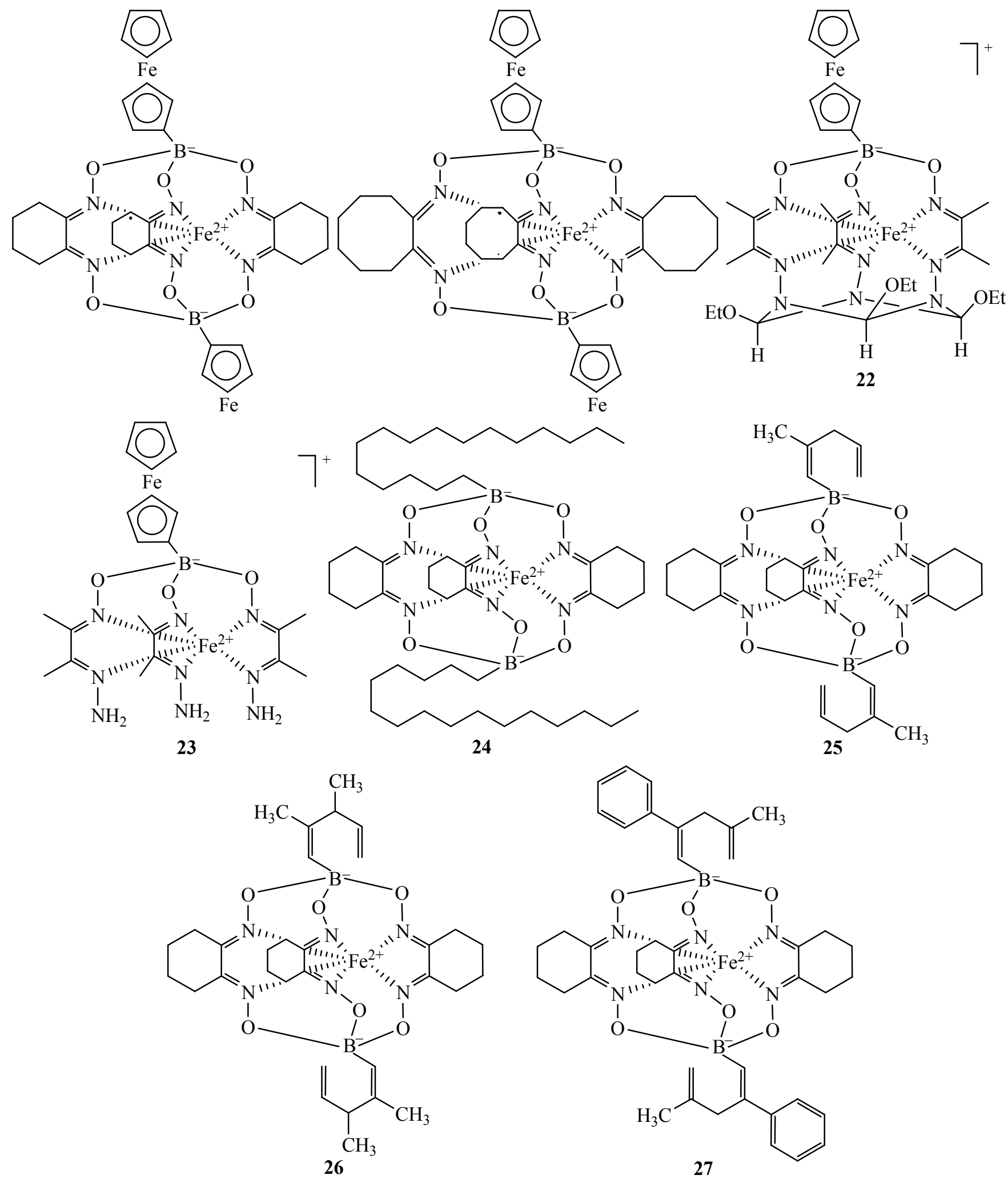




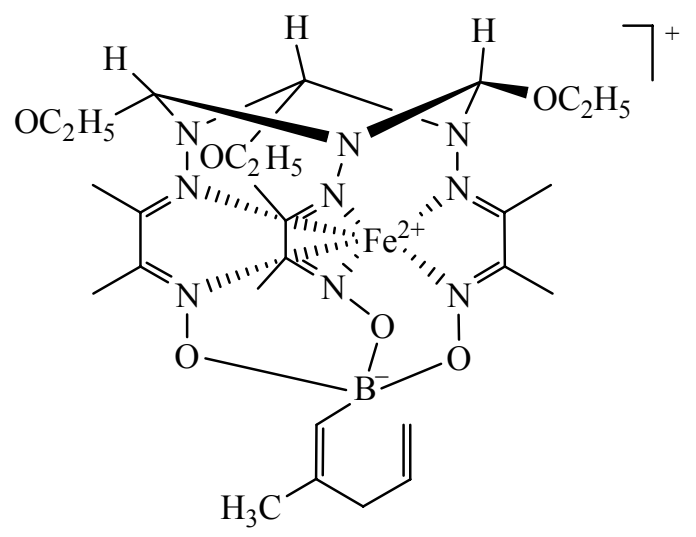

28

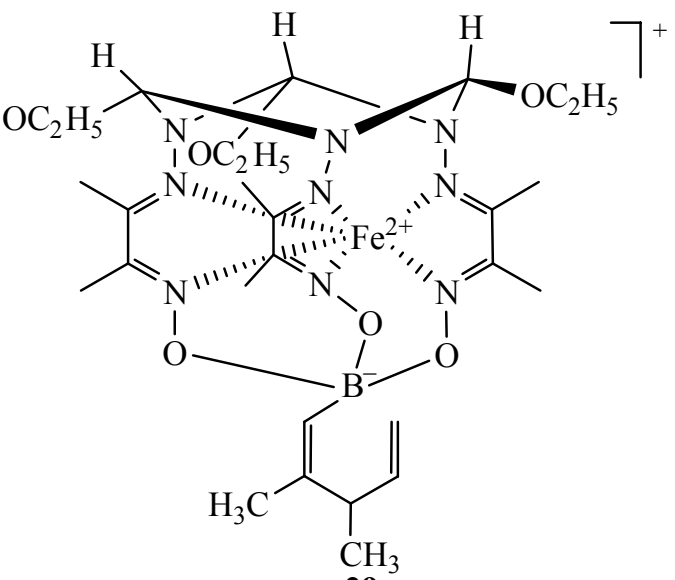

29

Scheme 9. (Contd.)

diketonates is unknown. However, assuming that the latter value is lower than $E_{\mathrm{p}}$, the heating should significantly affect the propagation reaction. It should weaken the inhibiting activity of $\beta$-diketonates as compared with the initiating activity [84]. Another approach towards weakening the inhibiting activity of $\beta$-diketonates in polymerization is the introduction of donor additives. Their effect is dual: on the one hand, the adduct of the chelate and the additive facilitates the radical formation, and hence enhances the initiating activity; on the other hand, the donor additive blocks the inner coordination sphere of the chelate, thus hindering its interaction with propagating radicals [83]. The application of cobalt(II) chelates as initiators in the emulsion polymerization of styrene has been studied as well $[84,85]$.

In [86], the in situ preparation of the catalyst via addition of the chelating ligands: $N, N, N, N$-tetramethylpropane-1,3-dimanine, $N, N$-dimethyl-[2-(diphenylphosphino)phenyl]methaneamine, diphenylphosphinopropane, etc. to $\mathrm{FeBr}_{2}$ has been reported. It was shown that the so called "chelate effect" preserved the high activity of the catalyst throughout the polymerization process. Use of such substituents, especially the heterochelate complex containing nitrogen and phosphorus atoms, allows for controlled methyl methacrylate polymerization with the bromide initiator yielding the products with narrow molecular mass distribution.

A new type of catalysts, ferrocenyl-containing iron(II) semi- and clathrochelates, remarkable for the presence of ferrocenyl fragment (or fragments) in the clathrochelate scaffold 20-29 (Scheme 9) has been suggested in [87-92]. The choice of such structure of the complex has been inspired by the presence of highly reactive ferrocenyl group $[33,55,63]$ as well as by the special ligand type, macrocyclic clathrochelate with iron(II) as the central atom. Complexes of such structure can more efficiently (as compared to ferrocenes) affect the microstructure of the prepared poly (methyl methacrylate) owing to the enhanced coordination capacity for retaining the monomer and the propagating macroradical in the sphere of the metal [either the central iron(II) or iron atoms of the ferrocenyl fragment]. However, the content of syndiotactic structures in the polymer has not been much improved using such catalysts. Nevertheless, the kinetic results have been promising: the ferrocenyl-containing clathrochelates in combination with peroxide or hydroperoxide initiators form the catalytic/initiating systems significantly more active than ferrocene and its derivatives (see table).

Introduction of bisferrocenylborate macrobicyclic iron(II) tris(dioximate) $\mathbf{2 0}$ and $\mathbf{2 1}$ into the methyl methacrylate polymerization initiated with diacyl peroxides made it possible to get a sufficiently high process rate at $30-75^{\circ} \mathrm{C}$ [87-89]. Increasing the clathrochelate concentration from 0.01 to $0.02 \mathrm{mmol} / \mathrm{L}$ has accelerated the polymerization, but further increase of the complex content has retarded the process. Effective activation energy of the process is $48 \pm$ $5 \mathrm{~kJ} / \mathrm{mol}$, and the initiation rate $5.3 \times 10^{-7} \mathrm{~mol} \mathrm{~L}^{-1} \mathrm{~s}^{-1}$ is about 7 times higher than that in the case of polymerization in the presence of benzoyl peroxide alone. Application of ferrocenyl-containing clathrochelates will reduce the consumption of peroxide initiators 10-20 times. The acceleration of the initiation is owing to the peroxide interaction with the 
Scheme 10.

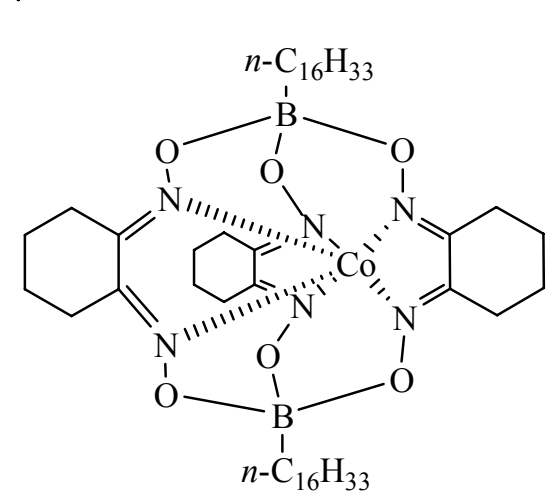

30

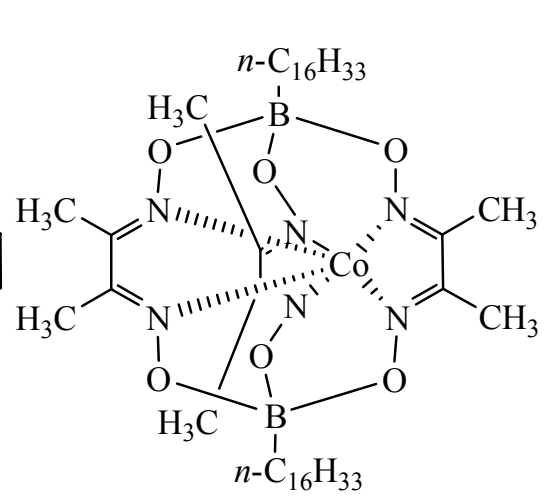

31

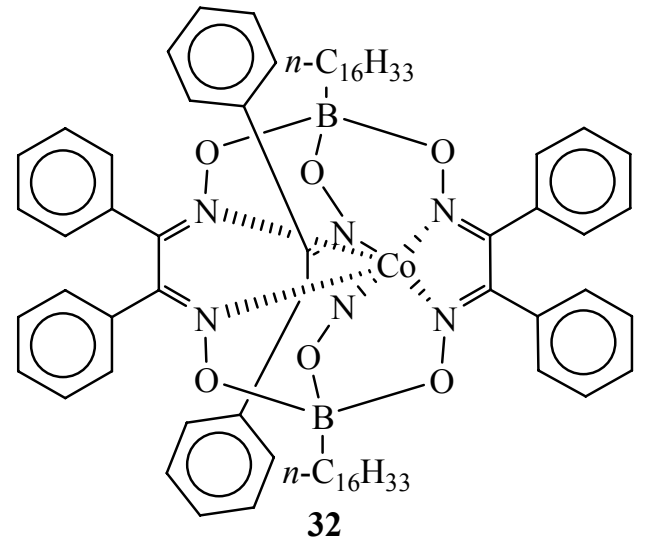

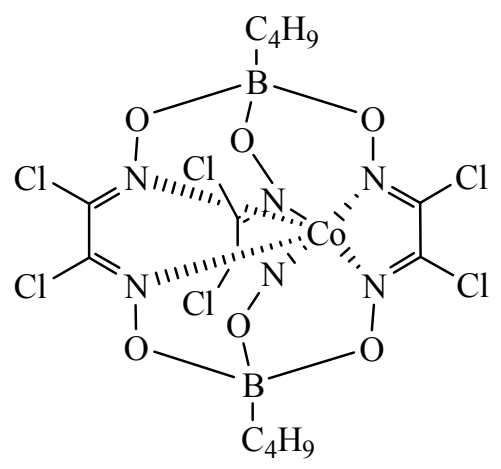

33

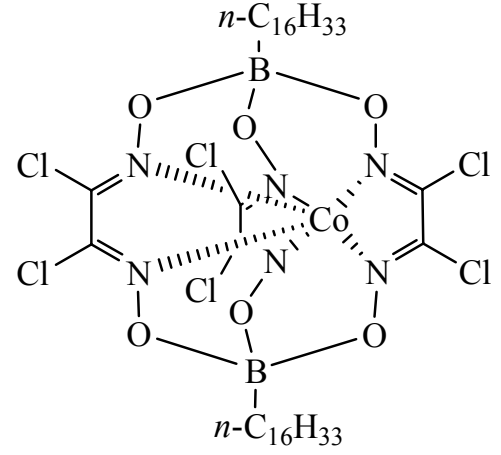

34 ferrocenyl fragments of the clathrochelate complex as well as with iron of the clathrochelate scaffold.

The presence of ferrocenyl-containing clathrochelate iron(II) complex has affected the content of syndiotactic fragments in the polymerization product (up by $6-9 \%$ as compared to the case of initiation with benzoyl peroxide alone), on top of the effect upon the kinetics of polymerization. The temperature onset of decomposition of poly(methyl methacrylate) and polystyrene prepared in the presence of ferrocenylcontaining clathrochelates has been $20-50^{\circ} \mathrm{C}$ higher as compared with the reference samples.

Oximehydrazonate iron(II) clathrochelates 22 and $\mathbf{2 3}$ as well as tris(dioximate) complexes $\mathbf{2 0}$ and $\mathbf{2 1}$ have been recognized as efficient catalysts/mediators of radical polymerization [89].

The effect of macrobicyclic complexes 24-29 containing no ferrocenyl fragments has been studied [90]. It has been found that these compounds are significantly less active in radical polymerization processes than their ferrocenyl-containing analogs.

The effect of macrobicyclic cobalt(II) tris- $\alpha$-dioximates with alkyl, aryl, and halide side substituents 30-
34 (Scheme 10) on radical polymerization of vinyl monomers has been studied in [91, 92]. Regardless of the used initiator type, the introduction of cobalt(II) clathrochelates in polymerization of methyl methacrylate and styrene has led to the character of the controlled macrochain growth: complete degeneration of the gel effect, the linear dependence of $M_{\mathrm{n}}$ on the monomer conversion, the decrease in the polydispersity index down to $M_{\mathrm{w}} / M_{\mathrm{n}}=1.8$ at a high conversion, and overall deceleration of the process with the increased concentration of the additives.

In order to elucidate the effect of the central metal ion of the clathrochelate on radical polymerization process, iron compounds with halide substituents 3537 (Scheme 11), similar to the cobalt complexes, has been studied [92]. The iron(II) complexes has been recognized as fairly inert towards polymerization as compared to the cobalt analogs (as reflected in the kinetic curves and the molecular mass of the products). Nevertheless, the relative polydispersity at a high conversion $\left(M_{\mathrm{w}} / M_{\mathrm{n}}<2.0\right)$ has been typical of the systems operating via the "living" mechanism.

To summarize, iron (clathro)chelates are generally efficient catalysts/mediators of radical polymerization 


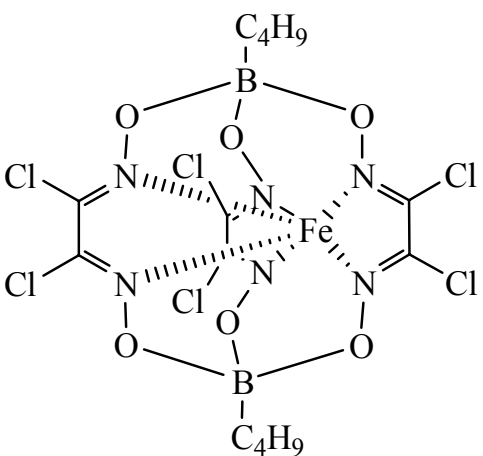

35
Scheme 11.

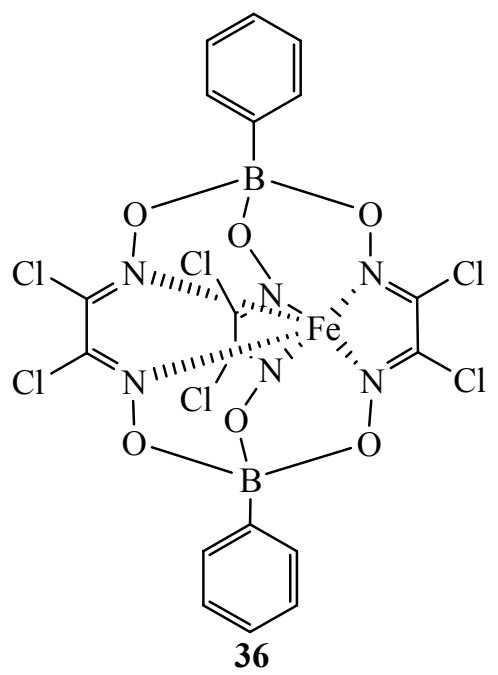

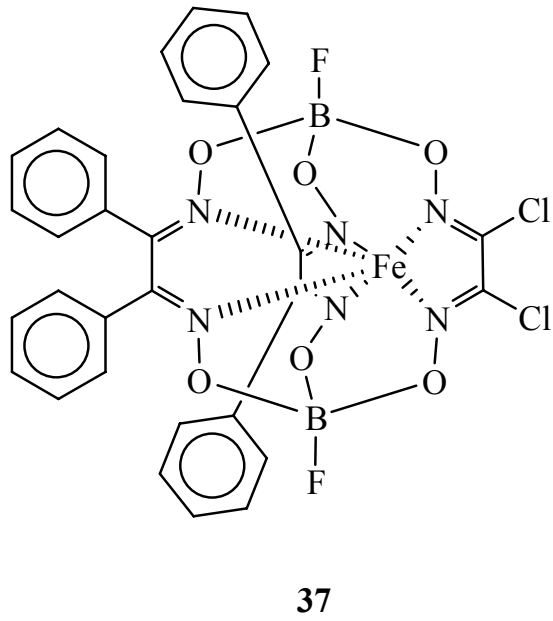

of vinyl monomers, allowing for the process control and affecting the properties of the prepared polymers.

Metal complexes with porphyrins. The investigation of porphyrins application in radical polymerization started about 40 years ago. In the studied cases the metal complexes of porphyrins have been applied as a part of the binary initiating system of the transition metal ion-hydroperoxide type [93]. The most important finding has been made using cobalt porphyrins: reactions of catalytic chain transfer to the monomer and of catalytic inhibition have been observed [94, 95]. Later it has been recognized that cobalt(II) tetramesitylporphyrinate and its octabrominated derivative initiate "living" polymerization of acrylates affording homopolymers and block copolymers. The products $M_{\mathrm{n}}$ increases linearly with the monomer conversion, and the polydispersity index is fairly low $\left(M_{\mathrm{w}} / M_{\mathrm{n}}=1.09-1.11\right)[96,97]$.

Manganese(III) porphyrinates have been used to initiate ring-opening polymerization of epoxides yielding polyethers exhibiting narrow molecular mass distribution [98]. Molecular mass of the prepared polymers can be controlled by altering the molar ratio of the solvent and the initiator, and by the addition of fresh portions of monomer inducing further polymer chains growth. The results have suggested that the process occurs in the "living" chains mode and that complexes of manganese(III) porphyrinates are universal initiators affording polyethers of the required molecular mass with a narrow molecular mass distribution.

Complexes of aluminum(II) porphyrinates with alkyl (Me, Et) extra ligands initiate "living" poly- merization of polar monomers like acrylates and methacrylates, whereas chloride, alcoholate, phenolate, and carboxylate extra ligands are not active in this reaction [99]. Sequential polymerization of acrylates in the presence of aluminum(III) porphyrinates has afforded block copolymers like polymethacrylatepolyether, polyacrylate-polymethacrylate, etc.

Rhodium(II) porphyrinates have been applied as catalysts to control polymerization of acrylic esters initiated by photo irradiation as well [100]. However, in this case molecular mass distribution of the prepared polymers was broad $\left(M_{\mathrm{w}} / M_{\mathrm{n}}=1.75-2.76\right)$.

The influence of titanyl, zirconium, and cobalt complexes of 5,10,15,20-tetrakis(3',5'-di-tert-butylphenyl)porphyrin on radical polymerization of methyl methacrylate has been studied [101-107]. These porphyrinates retain the high efficiency at a low polymerization temperature.

The most interesting results has been obtained in the studies of chlorine-containing complexes of iron(III) 5,10,15,20-tetrakis(3',5'-di-tert-butylphenyl)- (38), 5,10,15,20-tetrakis(3'-butoxyphenyl)- (39), and 5,15bis(4'-tert-butylphenyl)-2,8,12,18-tetra-(n-butyl)-3,7,13,17tetramethylporphyrinate (40) (Scheme 12).

It has been demonstrated that the introduction of the chlorinated iron porphyrinates in methyl methacrylate polymerization initiated with AIBN results in degeneration of the gel effect, and the monomer conversion is practically linear with time. Molecular mass of the so prepared polymers is lower as compared to poly(methyl methacrylate) prepared in the absence of porphyrinates [108-113]. 
Scheme 12.

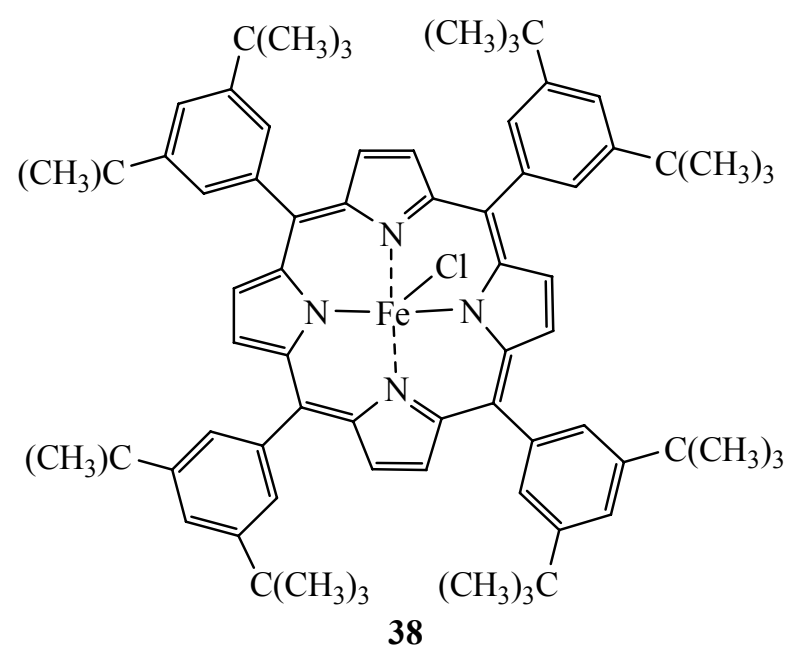

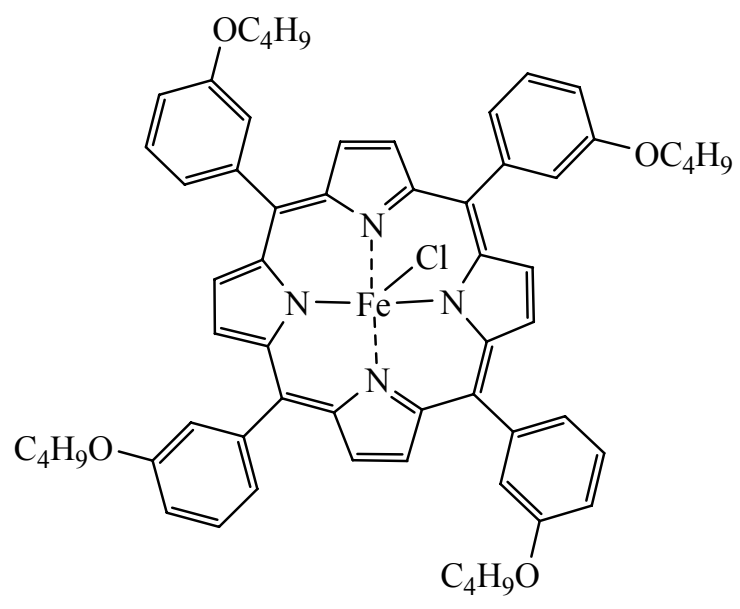

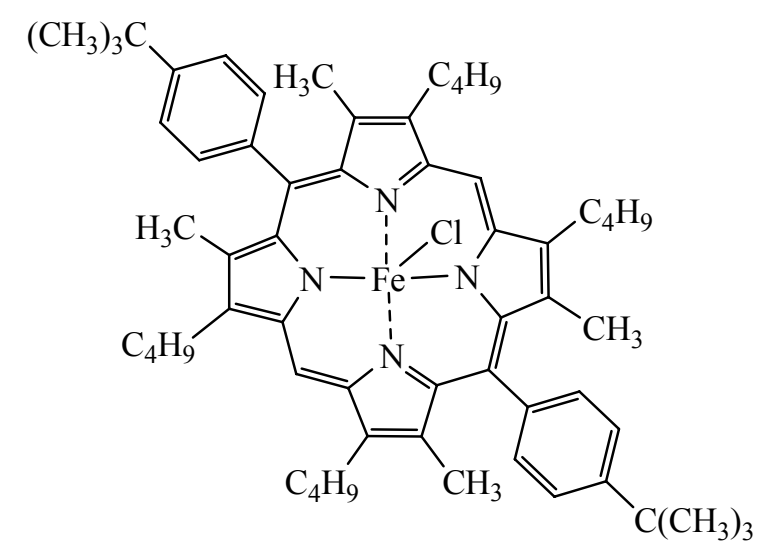

40

Besides the control of molecular mass distribution, the chlorinated iron porphyrinates affect the stereochemistry of the produced macromolecules; in particular, the content of syndiotactic fragments in the poly(methyl methacrylate) chains has been up by $5 \%$ on the average. Temperature onset of decomposition of poly(methyl methacrylates) prepared using the mentioned complexes has increased by approximately $20^{\circ} \mathrm{C}$. The low-temperature peak at the DTG curves around $247^{\circ} \mathrm{C}$ has vanished, and the decomposition occurred fast over the relatively narrow temperature range $\left(270-380^{\circ} \mathrm{C}\right)$ [108-113].

Styrene polymerization in bulk at $100^{\circ} \mathrm{C}$ initiated with AIBN in the presence of chlorinated iron porphyrinates has been studied till high conversion of the monomer. The properties of the so prepared polystyrene (uniformity, color, and molecular parameters) are analogous to these of poly(methyl methacrylate) prepared in the presence of such complexes. Molecular mass of the so prepared polystyrene has been about 23 times smaller as compared to the reference samples prepared in the presence of AIBN alone; the $M_{\mathrm{n}}$ value linearly increases with the monomer conversion; and the polydispersity index is of $M_{\mathrm{w}} / M_{\mathrm{n}}=1.65-1.80$, almost independently of the conversion. The molecular mass distribution curves are unimodal, being regularly shifted towards higher molecular mass with the increasing conversion. Temperature onset of decomposition of polystyrene prepared in the presence of the mentioned iron complexes has increased by $25^{\circ} \mathrm{C}$ as compared to the reference sample prepared in the presence of the radical initiator alone. Acrylic and methacrylic monomers have been recognized as more reactive in polymerization process than styrene. However, the general pathway of styrene and methyl 
Scheme 13.

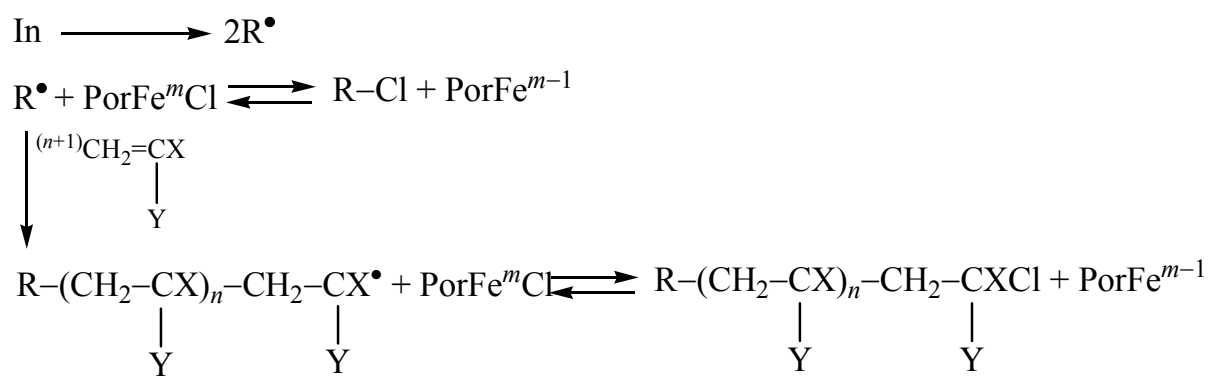

(In) is the initiator, $\left(\mathrm{R}^{*}\right)$ is the initiator radical, $\left(\mathrm{PorFe}^{m} \mathrm{Cl}\right)$ is the chlorinated iron porphyrinate, and $(\mathrm{Y})$ is $\mathrm{C}_{6} \mathrm{H}_{5}$ or $\mathrm{COOCH}_{3}$.

methacrylate polymerization upon initiation with AIBN has been the same, and the overall mechanism is reduced to RATRP (Scheme 13) [43, 108-113].

In general, behavior of the studied chlorinated iron porphyrinates $\mathbf{3 8}-\mathbf{4 0}$ in polymerization processes is similar. A special feature of the process has been sharp retardation of methyl methacrylate polymerization in the presence of these iron complexes and benzoyl peroxide, whereas styrene polymerization under the same conditions occurs till high conversion of the monomer, and molecular parameters of the so prepared polystyrene are typical of the "living" propagation of macromolecules [43, 108-113].

Interesting data have been obtained in the study of methyl methacrylate copolymerization with iron(III) complex of methyl pheophorbide A [114-116], the latter acting both as comonomer incorporated in the product chain and as controlling additive facilitating the "living" free radical polymerization via SFRP (Stable Free Radical Polymerization) or OMRP mechanism [11]. The major pathway of the reaction can be controlled by varying the solvent nature. In the case of benzene as solvent, copolymerization of methyl methacrylate and the iron(III) complex via the double bonds prevails, likely, due to the partial suppression of the "living" path because of iron ion shielding with aromatic solvent molecules. In the case of chloroform as solvent, the "living" propagation of the polymer chains becomes the dominating pathway. The structure of the iron(III) complex incorporated in the poly(methyl methacrylate) chain has not significantly changed, and the prepared copolymer thus exhibits the spectral (electron absorption, ESR, and luminescence) properties typical of the monomeric complex of iron(III) with methyl pheophorbide A. Numberaverage molecular mass of the copolymers prepared in bulk is linear with conversion, and the polydispersity index decreases with conversion to reach $M_{\mathrm{w}} / M_{\mathrm{n}}=$ 1.30-1.40. The prepared copolymer is capable of initiating methyl methacrylate polymerization showing the parameters typical of the "living" propagation.

In summary, metal complexes with porphyrins are peculiar compounds, highly active in controlled radical polymerization processes.

Comparison of selected iron complexes. This section presents comparative analysis of the effects of certain iron complexes (ferrocenes 1 [33], 7 [61], 8-12 [63], clathrochelates 20-23 [87, 89], 24-29 [90], and porphyrinates 30-32 [108-110]) on radical polymerization of vinyl monomers (methyl methacrylate and styrene) initiated with two types of initiators (benzoyl peroxide and AIBN).

The table contains the experimental parameters of the polymerization process and of the polymers prepared using different iron compounds; below the series of activity of iron-containing complexes in combination with the initiators of different nature are given.

Series of activity of metal complex compounds in combination with peroxide initiators in polymerization of vinyl monomers

$$
\begin{aligned}
20-23>8-12 & >1>(1 \text { and } 6) \geq 7>24-29 \\
23 & \approx 22 \geq 21 \approx 20>24-29 \\
10 & >12 \geq 11>8>9
\end{aligned}
$$

(only at polymerization temperature of $60^{\circ} \mathrm{C}$ )

$$
\begin{aligned}
24=25 & =26=27=28=29 \\
(1 \text { and } 6) & >(2 \text { and } 6) \geq(3 \text { and } 6) \\
1 & >(1 \text { and } 6)>>6 \\
2 & >(2 \text { and } 6)>6 \\
3 & >(3 \text { and } 6)>6 \\
32 & \geq 31 \geq 30
\end{aligned}
$$


Series of activity of metal complex compounds in combination with AIBN in polymerization of vinyl monomers

$$
\begin{gathered}
8-12>24-29>20-23 \approx 7 \geq(1 \text { and } 6) \approx 1 \\
8=9=10=11=12 \\
24=25=26=27=28=29 \\
20=21=22=23 \\
(1 \text { and } 6) \approx(2 \text { and } 6) \approx(3 \text { and } 6) \\
30 \geq 31 \geq 32
\end{gathered}
$$

Influence on initiation. Ferrocenes (1 [33], 7 [61], 8-12 [63]) and iron(II) clathrochelates (20-23 [87, 89], 24-29 [90]) affect the initiation stage, forming highly efficient initiating systems with peroxides (diacyl peroxides or hydroperoxides); however, they do not interact with AIBN. The spectral data collected for these systems has confirmed formation of the charge transfer complexes between the metal-containing compound and the peroxide; the complex decomposition gives free radicals and thus accelerates the initial and the overall polymerization rate, increases the initiation rate, decreases the effective activation energy, and reduces molecular mass of the formed polymers.

In the case of iron(III) porphyrinates (30-32 [108110]), the situation is the opposite: with benzoyl peroxide as initiator, methyl methacrylate polymerization has been sharply slowed down, whereas the polymerization initiated with AIBN occurs till high conversion under the same conditions. Quantumchemical simulations [117] have confirmed the possibility of formation of inactive products via interaction of the peroxide with chlorinated iron porphyrinates. The medium (monomer) polarity should be taken into account as well. Evidently, the coordination of the porphyrinate and the peroxide is facilitated in the polar methyl methacrylate as compared to the non-polar styrene, resulting in the faster disappearing of the free radicals initiating the polymerization in the former case.

Influence on propagation and chain termination. The effect of the iron complexes on propagation and termination stages has been confirmed in the study of compound 20-benzoyl peroxide system: the increase in the $k_{\mathrm{p}} /\left(k_{\mathrm{t}}\right)^{1 / 2}$ ratio resulting either from increase in $k_{\mathrm{p}}$ or decrease in $k_{\mathrm{t}}$ [87]. In the case of ferrocene 8 benzoyl peroxide system, the $k_{\mathrm{p}} /\left(k_{\mathrm{t}}\right)^{1 / 2}$ ratio is close to that for methyl methacrylate polymerization initiated with the peroxide alone [63]. However, azinyl ferrocenes increase the overall polymerization rate (and, hence, the $k_{\mathrm{p}}$ value) in the case of initiation with AIBN. Such increase in $k_{\mathrm{p}}$ is caused also by the clathrochalates containing no ferrocenyl groups [90]. At the same time, ferrocenyl-containing clathrochelates 20-23, structurally similar to the 24-29 clathrochelates, may accelerate the polymerization in the presence of the peroxide as well as the azo initiator.

The ferrocenes, clathrochelates, and porphyrinates effect on the propagation stage has been confirmed by the changes in the microstructure of the prepared poly (methyl methacrylate): the content of the syndiotactic structures increases by up to $\approx 10 \%$ irrespectively of the initiator nature. This is likely caused by the formation of the intermediate metal-containing compound-monomer-macroradical complexes, facilitating the preliminary spatial coordination of methyl methacrylate molecules and enhancing the stereospecificity of the chain propagation stage. Noteworthily, poly(methyl methacrylate) with stereoregularity close to $100 \%$ (as in the case of the ioncoordination polymerization) has not been obtained so far via the radical polymerization. Evidently, the experiment "senses" only certain part of the controlled process in the overall free-radical mechanism; however, this contribution is well enough to affect kinetics of the process and the polymer product properties.

Important feature of the polymers prepared using iron complexes is the improved thermal stability, by up to $(20-50)^{\circ} \mathrm{C}$, depending on the process conditions. The enhanced thermal stability might be assigned to the formation of more regular polymer structure; however, the content of syndiotactic structures is generally varied within relatively narrow range, 60$70 \%$. Hence, the improved thermal stability is likely due to the formation of more stable terminal fragments containing the metal complexes, confirming the iron species effect on the termination stage.

Influence of monomer nature. Complexes between the metal-containing additives and peroxide initiators are more readily formed in the polar methyl methacrylate than in the less polar styrene. This is reflected in the kinetic features: polymerization of methyl methacrylate in the presence of metal complexes and benzoyl peroxide occurs faster than styrene polymerization under the same conditions. However, behavior of iron complexes in polymerization of methyl methacrylate and styrene is in general similar.

Influence on molecular parameters of polymers. When using ferrocenes and clathrochelates, molecular 


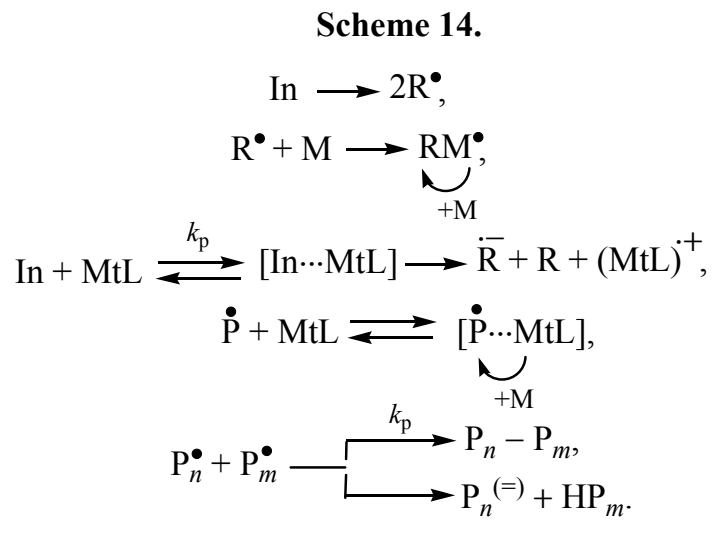

(In) is the initiator, $\left(\mathrm{R}^{\circ}\right)$ is the initiator radical, $(\mathrm{M})$ is monomer, $(\mathrm{MtL})$ is metal complex, and $\left(\mathrm{P}^{*}\right)$ is the macroradical.

parameters of the formed polymers can be affected by changing the process conditions (concentrations and ratios of the components, temperature, etc). However, the polydispersity index of the product prepared in the presence of the discussed complexes cannot be significantly decreased. In this regard, the systems based on chlorinated iron porphyrinates and AIBN [109-111] as well as bimetallocene catalytic/initiating systems [6871] are promising, inducing the "living" process during polymerization of methyl methacrylate and styrene.

Mechanism. In view of the available experimental data, it can be concluded that the character of metalcomplex radical polymerization is observed in the presence of ferrocenes (1 [33], 7 [61], 8-12 [63]), clathrochelates (20-23 [87, 89], 24-29 [90]), and iron porphyrinates (30-32 [108-110]). On the one hand, active initiating systems are formed via the interaction of iron complexes and the initiator, increasing the number of free radicals initiating the polymerization. On the other hand, iron complexes are coordinated with monomers and macroradicals, leading to the more regular polymer chain growth (Scheme 14).

When using chlorinated iron porphyrinates as well as the combined systems of two melallocenes 1-3 or 4-benzoyl peroxide, the polymerization occurs in the "living" mode.

In summary, metal complexes [in particular, substituted and unsubstituted ferrocenes, iron (clathro)chelates and iron porphyrinates] are efficient catalysts of controlled radical polymerization occurring via "living" and metal-complex mechanisms. Accounting for the available experimental data, behavior of the metal complexes in polymerization of methyl methacrylate, styrene, and other vinyl monomers can be predicted. Moreover, the variation of the initiators nature and structure of the metal complexes used as catalysts will allow for control of the polymerization process direction and preparation of various polymer products with desired properties.

\section{ACKNOWLEDGMENTS}

This work was financially supported by Russian Foundation for Basic Research (project no. 14-0300260-a).

\section{REFERENCES}

1. Matyjaszewski, K. and Xia., J., Chem. Rev., 2001, vol. 101, no. 9, p. 2921. DOI: 10.1021/cr940534g.

2. Kamigaito, M., Ando, T., and Sawamoto, M., Chem. Rev., 2001, vol. 101, no. 12, p. 3689. DOI: 10.1021/ cr9901182.

3. Di Lena, F. and Matyjaszewski, K., Progr. Polym. Sci., 2010, vol. 35, no. 8, p. 959. DOI:10.1016/ j.progpolymsci.2010.05.001.

4. Kamigaito, M., Ando, T., and Sawamoto, M., Chem. Record., 2004, vol. 4, no. 3, p. 159. DOI: 10.1002/ tcr.20011.

5. Grishin, I.D. and Grishin, D.F., Russ. Chem. Rev., 2008, vol. 77, no. 7, p. 633. DOI: 10.1070/ RC2008v077n07ABEH003790.

6. Poli, R., Angew. Chem. Int. Ed., 2006, vol. 45, no. 31, p. 5058. DOI: 10.1002/anie.200503785.

7. Ouchi, M., Terashima, T., and Sawamoto, M., Chem. Rev., 2009, vol. 109, no. 11, p. 4963. DOI: 10.1021/ cr900234b.

8. Islamova, R.M. and Monakov, Yu.B., Polym. Sci. Ser. (C), 2011, vol. 53, no. 1, p. 27. DOI: 10.1134/ S1811238211060026.

9. Hurtgen, M., Detrembleur Ch., Jerome Ch., and Debuigne, A., Polym. Rev., 2011, vol. 51, no. 2, p. 188. DOI: 10.1080/ 15583724.2011.566401.

10. Allan, L.E.N., Perry, M.R., and Shaver, M.P., Progr. Polym. Sci., 2012, vol. 37, no. 1, p. 127. DOI: $10.1016 /$ j.progpolymsci., 2011.07.004.

11. Poli, R., Allan, L.E.N., and Shaver, M.P., Progr. Polym. Sci., 2014, vol. 39, no. 10, p. 1827. DOI: $10.1016 /$ j.progpolymsci., 2014.06.003.

12. Hawker, C.J., Bosman, A.W., and Harth, E., Chem. Rev., 2001, vol. 101, no. 12, p. 3661. DOI: 10.1021/ cr990119u.

13. Sciannamea, V., Jerome, R., and Detrembleur Ch., Chem. Rev., 2008, vol. 108, no. 3, p. 1104. DOI: 10.1021/cr0680540.

14. Nicolas, J., Guillaneuf Yo., Lefay, C., Bertin, D., Gigmes, D., and Charleux, B., Progr. Polym. Sci., 2013, vol. 38, no. 1, p. 63. DOI: 10.1016/ j.progpolymsci.2012.06.002. 
15. Moad, G., Rizzardo, E., and Thang, S.H., Acc. Chem. Res., 2008, vol. 41, no. 9, p. 1133. DOI: 10.1021/ ar800075n.

16. Moad, G., Rizzardo, E., and Thang, S.H., Chem. Asian $J$. , 2013, vol. 8, no. 8, p. 1634. DOI: 10.1002/ asia.201300262.

17. Kabanov, V.A., Zubov, V.P., and Semchikov, Yu.D., Kompleksno-radikal'naya polimerizatsiya (ComplexRadical Polymerization), Moscow: Khimiya, 1987.

18. Grishin, D.F. and Semyonycheva, L.L., Russ. Chem. Rev., 2001, vol. 70, no. 5, p. 425. DOI: 10.1070/ RC2001v070n05ABEH000635.

19. Isobe, Yu., Nakano, T., Okamoto, Y., J. Polym. Sci. (A), 2001, vol. 39, no. 9, p. 1463. DOI: 10.1002/pola.1123.

20. Kamigaito, M. and Satoh, K., Macromolecules, 2008, vol. 41, no. 2, p. 269. DOI: 10.1021/ma0714991.

21. Satoh, K. and Kamigaito, M., Chem. Rev., 2009, vol. 109, no. 11, p. 5120. DOI: 10.1021/cr900115u.

22. Monakov, Yu.B., Puzin, Yu.I., Zaikina, A.V., Fatykhov, A.A., Zaikov, G.E., J. Appl. Polym. Sci., 2007, vol. 103, no. 2, p. 724. DOI: 10.1002/app. 24982.

23. Puzin, Yu.I., Prokudina, E.M., Muslukhov, R.R., and Kolesov, S.V., Doklady Phys. Chem., 2002, vol. 386, nos. 1-3, p. 211. DOI: 0012-5016/02/0009-0211.

24. Islamova, R.M., Puzin, Yu.I., Yumagulova, R.Kh., Fatykhov, A.A., Parfenova, L.V., Dzhemilev, U.M., and Monakov, Yu.B., Polym. Sci. (B), 2006, vol. 48, no. 7, p. 712. DOI: 10.1134/S0965545X06070078.

25. Schroder, K., Konkolewicz, D., Poli, R., and Matyjaszewski, K., Organometalics, 2012, vol. 31, no. 22, p. 7994. DOI: 10.1021/om3006883.

26. Zhang, Ya, Wang, Yu, Peng Chi-how, Zhong, M., Zhu, W., Konkolewicz, D., and Matyjaszewski, K., Macromolecules, 2012, vol. 45, no. 1, p. 78. DOI: 10.1021/ma201963c.

27. Bryliakov, K.P., Russ. Chem. Rev., 2007, vol. 76, no. 3, p. 253. DOI: 10.1070/RC2007v076n03ABEH003649.

28. Chen, E.Y.X. and Marks, T.J., Chem. Rev., 2000, vol. 100, no. 4, p. 1391. DOI: 10.1021/cr980462j.

29. Ittel, S.D., Johnson, L.K., and Brookhart, M., Chem. Rev., 2000, vol. 100, no. 4, p. 1169. DOI: 10.1021/ cr9804644.

30. Puzin, Yu.I., Yumagulova, R.Kh., Kraikin, V.A., Ionova, I.A., and Prochuchan, Yu.A., Polym. Sci. (B), 2000, vol. 42, nos. 3-4, p. 90.

31. Yumagulova, R.Kh., Cand. Sci. (Chem.) Dissertation, Ufa, 2000. 24 c.

32. Kraikin, V.A., Ionova, I.A., Puzin, Yu.I., Yumagulova, R.Kh., and Monakov, Yu.B., Polym. Sci. (B), 2000, vol. 42, no. 9, p. 1573.

33. Puzin, Yu.I., Yumagulova, R.Kh., and Kraikin, V.A., Eur. Polymer J., 2001, vol. 37, no. 9, p. 1801. DOI: 10.1016/S0014-3057(01)00038-6.

34. Puzin, Yu.I., Yumagulova, R.Kh., Budtov, V.P., Kolesov, S.V., and Monakov, Yu.B., Polym. Sci. (B), 2005, vol. 47, nos. 3-4, p. 72.

35. Sigaeva, N.N., Kolesov, S.V., Prokudina, E.M., Nikonchuk, E.Yu., and Monakov, Yu.B., Doklady
Chem., 2002, vol. 386, nos. 4-6, p. 285. DOI: 00125008/02/0010-0285.

36. Kolesov, S.V., Yumagulova, R.Kh., Prokudina, E.M., Puzin, Yu.I., Kuznetsov, S.I., and Ionova, I.A., Polym. Sci. (B), 2003, vol. 45, nos. 1-2, p. 13.

37. Grishin, D.F., Semyonycheva, L.L., Telegina, E.V., Smirnov, A.S., and Nevodchikov, V.I., Russ. Chem. Bull. Int. Ed., 2003, vol. 52, no. 2, p. 505. DOI: 10665285/03/5202-505\$25.00.

38. Kolesov, S.V., Sigaeva, N.N., and Friesen, A.K., Zakharova, E.M., Doklady Phys. Chem., 2009, vol. 424, no. 1, p. 21. DOI: 10.1134/S0012501609010060.

39. Agareva, N.A., Ivanov, V.F., Aleksandrov, A.P., Bityurin, N.M., and Smirnova, L.A., Polym. Sci. (A), 2004, vol. 46, no. 2, p. 105.

40. Telegina, E.V., Semyonycheva, L.L., and Grishin, D.F., Russ. J. Appl. Chem., 2004, vol. 77, no. 7, p. 1156. DOI: 1070.4272/04/7707-1156.

41. Grishin, D.F., Shchepalov, A.A., Telegina, E.V., Ignatov, S.K., Razuvaev, A.G., and Semyonycheva, L.L., Polym. Sci. (A), 2005, vol. 47, no. 6, p. 574.

42. Puzin, Yu.I. and Islamova, R.M., Prom. Proizv-vo. Isp. Elastomer., 2013, vol. 3, no. 3, p. 8.

43. Islamova, R.M., Doctoral (Chem.) Dissertation, Уфа, 2010.

44. Grognec, E.L., Claverie, J., and Poli, R., J. Am. Chem. Soc., 2001, vol. 123, no. 39, p. 9513. DOI: 10.1021/ ja010998d.

45. Stoffelbach, F., Poli, R., and Richard, P., J. Organomet. Chem., 2002, vol. 663, nos. 1-2, p. 269. DOI: 10.1016/ S0022-328X(02)01878-8.

46. Wang, B., Zhuang, Y., Luo, X., Xu, S., and Zhou, X., Macromolecules, 2003, vol. 36, no. 26, p. 9684. DOI: $10.1021 / \mathrm{ma} 035334 \mathrm{y}$.

47. Ando, T., Kamigaito, M., and Sawamoto, M., Macromolecules, 2000, vol. 33, no. 16, p. 5825. DOI: 10.1021/ ma9921596.

48. Watanabe, Y., Ando, T., Kamigaito, M., and Sawamoto, M., Macromolecules, 2001, vol. 34, no. 13, p. 4370. DOI: 10.1021/ma001990b.

49. Lorkovskii, K.D., Vysokomol. Soed., 1973, vol. 15, no. 2, p. 314.

50. Burova, T.V. and Fok, N.V., Doklady Akad. Nauk SSSR, 1981, vol. 258, no. 2, p. 379.

51. Ray, B., Isobe, Yu., Matsumoto, K., Habaue, Sh., Okamoto Yo., Kamigaito, M., and Sawamoto, M., Macromolecules, 2004, vol. 37, no. 5, p. 1702. DOI: $10.1021 / \mathrm{ma} 035119 \mathrm{~h}$.

52. Kamigaito, M. and Satoh, K., J. Polym. Sci. (A), 2006, vol. 44, no. 21, p. 6147. DOI: 10.1002/pola.21688.

53. Grassi, N. and Scott, J., Polymer Degradation and Stabilization, Cambridge, 1985.

54. Subramanian, K., J. Polym. Sci. (A), 1999, vol. 37, no. 22, p. 4090. DOI: 10.1002/(SICI)1099-0518 (19991115)37:22<4090::AID-POLA7>3.0.CO;2-R.

55. Islamova, R.M., Puzin, Yu.I., Fatykhov, A.A., and 
Monakov, Yu.B., Polym. Sci. (B), 2006, vol. 48, nos. 56, p. 130. DOI: 10.1134/S156009040605006X.

56. Puzin, Yu.I., Galinurova, E.I., Kuznetsov, S.I., Fatykhov, A.A., and Monakov, Yu.B., Polym. Sci. (A), 2002, vol. 44, no. 10, p. 1032.

57. Islamova, R.M., Puzin, Yu.I., Kraikin, V.A., Fatykhov, A.A., Dzhemilev, U.M., and Monakov, Yu.B., Russ. J. Appl. Chem., 2006, vol. 79, no. 9, p. 1509. DOI: 10.1134/S1070427206090229.

58. Islamova, R.M., Sadykova, G.R., Puzin, Yu.I., Vlasova, N.M., and Monakov, Yu.B., Vestn. Bashkirsk. Gos. Univ., 2007, vol. 12, no. 4, p. 28.

59. Islamova, R.M., Puzin, Yu.I., and Monakov, Yu.B., Prom. Proizv-vo. Isp. Elastomer., 2008, vol. 2, no. 2, p. 12.

60. Monakov, Yu.B., Puzin, Yu.I., Islamova, R.M., Kuznesov, S.I., Kraikin, V.A., and Fat'ykhov, A.A., J. Balkan Tribological Ass., 2006, vol. 12, p. 519.

61. Islamova, R.M., Zaikina, A.V., Puzin, Yu.I., and Monakov Yu.B., Vestn. Bashkirsk. Gos. Univ., 2008, vol. 13, no. 2, p. 261.

62. Monakov, Yu.B., Islamova, R.M., Golovochesova, O.I., Utepova, I.A., Musikhina, A.A., and Chupakhin, O.N., Doklady Chem., 2010, vol. 432, no. 2, p. 140. DOI: 10.1134/S001250081005006X.

63. Islamova, R.M., Golovochesova, O.I., Monakov, Yu.B., Utepova, I.A., Musikhina, A.A., and Chupachin, O.N., Polym. Sci. (B), 2010, vol. 52, nos. 11-12, p. 637. DOI: $10.1134 / \mathrm{S} 1560090410110023$.

64. Islamova, R.M., Golovochesova, O.I., Puzin, Yu.I., Chupahin, O.N., Abdullin, M.I., and Monakov, Yu.B., Prom. Proizv-vo. Isp. Elastomer., 2010, vol. 3, no. 3, p. 14.

65. Zaikina, A.V., Puzin, Yu.I., Kuznetsov, S.I., and Monakov, Yu.B., Izv. Vuzov, Ser. Khim. Khim. Tekhnol., 2006, vol. 49, no. 7, p. 117.

66. Islamova, R.M., Ishkinina, O.I., Nazarova, S.V., Chupakhin, O.N., Utepova, I.A., Andriyashina, N.M., and Terent'ev, A.O., Russ. Chem. Bull. Int. Ed., 2013, vol. 62, no. 5, p. 1282. DOI: 1066-5285/13/6205-1282.

67. Islamova, R.M., Puzin, Yu.I., Kuznetsov, S.I., Muslukhov, R.R., and Monakov, Yu.B., Izv. Vuzov, Ser. Khim. Khim. Tekhnol., 2007, vol. 50, no. 2, p. 62.

68. Islamova, R.M., Sadykova, G.R., Puzin, Yu.I., Spirikhin, L.V., Kraikin, V.A., and Monakov, Yu.B., Polym. Sci. (B), 2008, vol. 50, nos. 5-6, p. 128. DOI: 10.1134/ S1560090408050060.

69. Islamova, R.M., Puzin, Yu.I., Spirikhin, L.V., Kraikin, V.A., and Monakov Yu.B., Prom. Proizv-vo. Isp. Elastomer., 2008, vol. 1, no. 1, p. 16.

70. Monakov, Yu.B., Islamova, R.M., and Puzin, Yu.I., Recent Res. Devel. Appl. Polymer Sci., 2009, vol. 4, p. 169.

71. Monakov, Yu.B., Islamova, R.M., Frizen, A.K., Golovochesova, O.I., and Nazarova, S.V., Mendeleev Commun., 2011, vol. 21, no. 4. p. 206. DOI: 10.1016/ j.mencom.2011.07.012.

72. Murinov, Yu.I., Grabovskiy, S.A., Islamova, R.M., Kuramshina Al.R., and Kabal'nova, N.N., Mendeleev Commun., 2013, vol. 23, no. 1, p. 53. DOI: 10.1016/ j.mencom.2013.01.020.

73. Onishi, I., Baek, K.-Yo., Kotani, Yu., Kamigaito, M., and Sawamoto, M., J. Polym. Sci. (A), 2002, vol. 40, no. 12 , p. 2033. DOI: $10.1002 /$ pola.10299.

74. Kotani, Y., Kamigaiti, M., and Sawamoto, M., Macromolecules, 2000, vol. 33, no. 10, p. 3543. DOI: 10.1021/ ma991990f.

75. Kotani, Y., Kamigaiti, M., and Sawamoto, M., Macromolecules, 2000, vol. 33, no. 18, p. 6746. DOI: 10.1021/ ma000624p.

76. Fuji, Yu., Ando, T., Kamigaito, M., and Sawamoto, M., Macromolecules, 2002, vol. 35, no. 8, p. 2949. DOI: 10.1021/ma011714c.

77. Davydova, S.L., Barabanov, V.A., Plate, N.A., and Kargin, V.A., Vysokomol. Soed., 1968, vol. 10, no. 5, p. 1004.

78. Nikolaev, A.F., Belgorodskaya, K.V., Duvakina, N.I., and Andreeva, E.D., Vysokomol. Soed., 1971, vol. 13, no. 5 , p. 1018 .

79. Voloshanovskii, I.S., Mazurenko, G.A., and Krasnova, E.A., Zh. Obshch. Khim., 1989, vol. 59, no. 4, p. 755 .

80. Voloshanovskii, I.S., Butova, T.D., and Shevchenko, O.V., Zh. Obshch. Khim., 1999, vol. 69, no. 9, p. 1504.

81. Shevchenko, O.V., Voloshanovskii, I.S., Petrova, E.V., and Berbat, T.I., Russ. J. Appl. Chem., 2005, vol. 78, no. 3, p. 474. DOI: 1070-4272/05/7803-0474.

82. Voloshanovskii, I.S., Shevchenko, O.V., Butova, T.D., and Manaev, T.I., Russ. J. Appl. Chem., 2003, vol. 76, no. 2, p. 271. DOI: 1070-4272/03/7602-0271.

83. Shevchenko, O.V., Voloshanovskii, I.S., Burenkova, E.V., Russ. J. Appl. Chem., 2010, vol. 83, no. 2, p. 303. DOI: 10.1134/S1070427210020229.

84. Tsar'kova, M.S., Gritskova, I.A., Pisarenko, E.I., Levitin, I.Ya., and Sigan, A.L., Polym. Sci. (B), 2006, vol. 48, nos. 11-12, p. 335. DOI: 10.1134/ S15600904061110078.

85. Tsar'kova, M.S., Gritskova, I.A., Levitin, I.Ya., Sigan, A.L., and Kolyachkina, A.V., Polym. Sci. (A), 2007, vol. 49, no. 10 , p. 1065. DOI: 10.1134/S0965545X0710001X.

86. Uchiike Ch., Ouchi, M., Ando, T., Kamigaito, M., and Sawamoto, M., J. Polym. Sci. (A), 2008, vol. 46, no. 20, p. 6819. DOI: $10.1002 /$ pola.22990.

87. Islamova, R.M., Sadykova, G.R., Ionova, I.A., Voloshin, Ya.Z., Bubnov, Yu.N., Makarov, I.S., and Monakov, Yu.B., Polym. Sci. (B), 2009, vol. 51, nos. 78, p. 219. DOI: 10.1134/S1560090409070033.

88. Monakov, Yu.B., Islamova, R.M., Sadykova, G.R., Makarov, I.S., Voloshin, Ya.Z., and Bubnov, Yu.N., Russ. Chem. Bull. Int. Ed., 2009, vol. 58, no. 6, p. 1162. DOI: 1066-5285/09/5806-1162. 
89. Islamova, R.M., Sadykova, G.R., Monakov, Yu.B., Voloshin, Ya.Z., Makarov, I.S., and Bubnov, Yu.N., Russ. J. Appl. Chem., 2009, vol. 82, no. 8, p. 1467. DOI: $10.1134 / \mathrm{S} 1070427209080278$.

90. Monakov, Yu.B., Islamova, R.M., Sadykova, G.R., Voloshin, Ya.Z., Makarenko, I.G., Lebedev, A.Yu., and Bubnov, Yu.N., Doklady Chem., 2010, vol. 431, no. 1, p. 89. DOI: 10.1134/S0012500810030079.

91. Islamova, R.M., Golovochesova, O.I., Monakov, Yu.B., Voloshin, Ya.Z., Lebedev, A.Yu., and Bubnov, Yu.N., Doklady Chem., 2011, vol. 439, no. 1, p. 200. DOI: 10.1134/S0012500811070081.

92. Islamova, R.M., Ishkinina, O.I., Nazarova, S.V., Voloshin, Ya.Z., Belov, A.S., and Bubnov, Yu.N., Doklady Chem., 2012, vol. 447, no. 1, p. 244. DOI: 10.1134/S0012500812110067.

93. Porfiriny: struktura, svoistva, sintez (Porphyrins: Structure, Properties, and Synthesis), Enikolopyan, N.S., Ed., Moscow: Nauka, 1985.

94. Smirnov, B.R., Morozova, I.S., Pushchaeva, L.M., Marchenko, A.P., and Enikolopyan, N.S., Doklady Akad. Nauk SSSR, 1980, vol. 255, no. 3, p. 609.

95. Smirnov, B.R., Vysokomol. Soed., 1982, vol. 24, no. 4, p. 877.

96. Wayland, B.B., Poszmik, G., Mukerjee, S.L., and Fryd, M., J. Am. Chem. Soc., 1994, vol. 116, no. 17, p. 7943. DOI: $10.1021 /$ ja00096a080.

97. Wayland, B.B., Basickes, L., Mukerjee Sh., and Wei, M., Macromolecules, 1997, vol. 30, no. 26, p. 8109. DOI: 10.1021/ma9707493.

98. Porphyrin Handbook: Bioinorganic and Bioorganic Chemistry, Kadish, K.M., Smith, K.M., and Guilard, R., Eds., New York: Academic Press, 2000, p. 133.

99. Hosokawa, Y., Kuroki, M., Aida, T., and Inoue, S., Macromolecules, 1991, vol. 24, no. 4, p. 824. DOI: 10.1021/ma00004a002.

100. Wayland, B.B., Poszmik, G., and Fryd, M., Organometallics, 1992, vol. 11, no. 11, p. 3534. DOI: 10.1021/om00059a016.

101. Islamova, R.M., Nasretdinova, R.N., Puzin, Yu.I., Semeikin A.S., Koifman, O.I., and Monakov, Yu.B., Izv. Vuzov, Ser. Khim. Khim. Tekhnol., 2005, vol. 48, no. 12 , p. 54.

102. Islamova, R.M., Zaikina, A.V., Nasretdinova, R.N., Puzin, Yu.I., Semeikin A.S., Koifman, O.I., and
Monakov, Yu.B., Izv. Vuzov, Ser. Khim. Khim. Tekhnol., 2006, vol. 49, no. 5, p. 53.

103. Nasretdinova, R.N., Islamova, R.M., Koifman, O.I., and Monakov, Yu.B., Izv. Vuzov, Ser. Khim. Khim. Tekhnol., 2006, vol. 49. Вып. 8, p. 24.

104. Nasretdinova, R.N., Islamova, R.M., Ionova, I.A., and Monakov, Yu.B., Vestn. Bashkirsk. Gos. Univ., 2006, no. 4, p. 26.

105. Monakov, Yu.B., Koifman, O.I., Nasretdinova, R.N., Islamova, R.M., Puzin, Yu.I., and Ionova, I.A., J. Balkan Tribolog. Ass., 2006, vol. 12, no. 3, p. 294.

106. Islamova, R.M., Sadykova, G.R., Ionova, I.A., Syrbu, S.A., Koifman, O.I., and Monakov, Yu.B., Izv. Vuzov, Ser. Khim. Khim. Tekhnol., 2008, vol. 51, no. 3 , p. 65 .

107. Islamova, R.M., Monakov, Yu.B., Syrbu, S.A., Koifman, O.I., and Zaikov, G.E., Polym. Res. J., 2008, vol. 1, p. 471.

108. Islamova, R.M., Puzin, Yu.I., Syrbu, S.A., Koifman, O.I., and Monakov, Yu.B., Polym. Sci. (B), 2009, vol. 51, nos. 3-4, p. 110. DOI: 10.1134/S1560090409030075.

109. Monakov, Yu.B., Islamova, R.M., and Koifman, O.I., Macroheterocycles, 2009, vol. 2, nos. 3-4, p. 237.

110. Monakov, Yu.B., Islamova, R.M., Ionova, I.A., Syrbu, S.A., Ageeva, T.A., and Koifman, O.I., Mendeleev Commun., 2010, vol., 20, no. 1, p. 33. DOI: 10.1016/ j.mencom.2010.01.013.

111. Islamova, R.M., Izv. Vuzov, Ser. Khim. Khim. Tekhnol., 2010, vol. 53, no. 2, p. 16.

112. Islamova, R.M., Vestn. Bashkirsk. Gos. Univ., 2010, vol. 15 , no. 2 , p. 301.

113. Islamova, R.M., Nazarova, S.V., and Koifman, O.I., Macroheterocycles, 2011, vol. 4, no. 2, p. 97.

114. Islamova, R.M., Nazarova, S.V., Ageeva, T.A., Romanenko, Yu.V., and Koifman, O.I., Doklady Chem., 2012, vol. 446, no. 1, p. 188. DOI: 10.1134/ S0012500812090078.

115. Islamova, R.M., Nazarova, S.V., Ageeva, T.A., and Koifman, O.I., Mendeleev Commun., 2013, vol. 23, no. 5, p. 279. DOI: 10.1016/j.mencom.2013.09.014.

116. Islamova, R.M. and Nazarova, S.V., Prom. Proizv-vo. Isp. Elastomer., 2013, no. 4, p. 11.

117. Friesen, A.K., Macroheterocycles, 2009, vol. 2, nos. 3-4, p. 243. 